\title{
Development of Mast Cells and Importance of Their Tryptase and Chymase Serine Proteases in Inflammation and Wound Healing
}

\section{Citation}

Douaiher, Jeffrey, Julien Succar, Luca Lancerotto, Michael F. Gurish, Dennis P. Orgill, Matthew J. Hamilton, Steven A. Krilis, and Richard L. Stevens. 2014. “Development of Mast Cells and Importance of Their Tryptase and Chymase Serine Proteases in Inflammation and Wound Healing." Advances in Immunology: 211-252. doi:10.1016/b978-0-12-800267-4.00006-7.

\section{Published Version}

doi:10.1016/B978-0-12-800267-4.00006-7

\section{Permanent link}

http://nrs.harvard.edu/urn-3:HUL.InstRepos:32659595

\section{Terms of Use}

This article was downloaded from Harvard University's DASH repository, and is made available under the terms and conditions applicable to Other Posted Material, as set forth at http:// nrs.harvard.edu/urn-3:HUL.InstRepos:dash.current.terms-of-use\#LAA

\section{Share Your Story}

The Harvard community has made this article openly available.

Please share how this access benefits you. Submit a story.

Accessibility 


\title{
Development of Mast Cells and Importance of Their Tryptase and Chymase Serine Proteases in Inflammation and Wound Healing
}

\author{
Jeffrey Douaiher ${ }^{\star}$, Julien Succar ${ }^{\dagger}$, Luca Lancerotto ${ }^{\star}$, Michael F. Gurish ${ }^{\ddagger}$, Dennis P. Orgill ${ }^{\star}$,

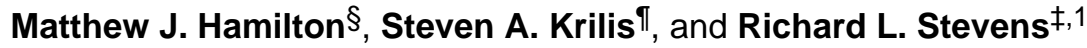 \\ "Division of Plastic Surgery, Department of Surgery, Brigham and Women's Hospital, Boston, \\ Massachusetts, USA \\ †Division of General Surgery, Department of Surgery, University of Kentucky, Lexington, \\ Kentucky, USA \\ ¥Division of Rheumatology, Immunology, and Allergy, Department of Medicine, Brigham and \\ Women's Hospital, Boston, Massachusetts, USA \\ §Division of Gastroenterology, Department of Medicine, Brigham and Women's Hospital, Boston, \\ Massachusetts, USA \\ IDepartment of Infectious Disease, Immunology, and Sexual Health, The St. George Hospital, \\ University of New South Wales, Kogarah, New South Wales, Australia
}

\begin{abstract}
Mast cells (MCs) are active participants in blood coagulation and innate and acquired immunity. This review focuses on the development of mouse and human MCs, as well as the involvement of their granule serine proteases in inflammation and the connective tissue remodeling that occurs during the different phases of the healing process of wounded skin and other organs. The accumulated data suggest that MCs, their tryptases, and their chymases play important roles in tissue repair. While MCs initially promote healing, they can be detrimental if they are chronically stimulated or if too many MCs become activated at the same time. The possibility that MCs and their granule serine proteases contribute to the formation of keloid and hypertrophic scars makes them potential targets for therapeutic intervention in the repair of damaged skin.
\end{abstract}

\section{INTRODUCTION}

Although mast cells (MCs) were discovered more than a century ago by Nobel Laureate Paul Ehrlich (Ehrlich, 1878), the importance of these immune cells in homeostasis and pathogen defense was appreciated only recently. MCs are not abundant in any tissue (Metcalfe, Baram, \& Mekori, 1997), and they complete their development only after their poorly granulated progenitors home to tissues (Fig. 6.1). Thus, the inability to obtain sufficient numbers of in vivo-differentiated mature MCs for study greatly hindered our

(C) 2014 Elsevier Inc. All rights reserved.

${ }^{1}$ Corresponding author: rstevens@ rics.bwh.harvard.edu. 
understanding of the importance of these cells and why they had been conserved for more than 500 million years of evolution. A contributing factor that prevented the identification of MC-restricted genes and transcripts was the observation that mature, in vivo-differentiated MCs contained very little mRNA relative to the contaminating cells in varied tissue preparations.

The discovery in the 1980s that the T-cell-derived factor interleukin (IL)-3 selectively promoted the viability, proliferation, and differentiation of a pluripotent population of mouse MCs from their hematopoietic progenitors that were free of contaminating cells finally facilitated the generation of large numbers of MCs for study (Razin, Cordon-Cardo, \& Good, 1981; Razin, Ihle, et al., 1984; Schrader, Lewis, Clark-Lewis, \& Culvenor, 1981). These in vitro-generated mouse bone marrow-derived MCs (mBMMCs) were less mature than those in the jejunum, skin, and other connective tissues. Nevertheless, the ability to generate nontransformed MCs in vitro from wild-type (WT) and transgenic mice on different genetic backgrounds allowed detailed studies on the developmental control and functions of these cells at the molecular level. The resulting data led to a better understanding of the importance of mouse MCs and their human equivalents in acquired and innate immunity, inflammation, and blood coagulation. The observation that IL-3-developed mBMMCs contained more mRNA on a per cell basis than mature in vivo-differentiated MCs enabled the identification and cloning of many of the MC's mediators (e.g., mouse MC protease (mMCP)-5 (McNeil, Austen, Somerville, Gurish, \& Stevens, 1991)), receptors (e.g., gp49B1/Lilrb4; Katz et al., 1996), and intracellular signaling proteins (e.g., RasGRP4; Yang et al., 2002). IL-3-developed mBMMCs have been used in nearly 1000 peer-reviewed publications. Since it was subsequently found that similar populations of MCs could be generated from fetal liver (Razin, Stevens, et al., 1984) and even embryonic stem cells (Tsai, Tam, Wedemeyer, \& Galli, 2002), IL-3-dependent mouse MCs were particularly valuable for evaluating at the molecular level the functions of ubiquitously expressed proteins like Rac2 (Gu et al., 2002) and other intracellular signaling proteins that are critical for embryonic development. Thus, the in vitro method developed by Razin, Ihle, et al. (1984) for generating IL-3-dependent mouse MCs was a major technological advance.

The identification of "reaginic" immunoglobulin by the Ishizakas in the 1960s (Ishizaka, Ishizaka, \& Hornbrook, 1966) led to the discovery that the IgE-dependent activation of MCs can result in life-threatening systemic anaphylaxis. The generation of mBMMCs and numerous variants (McGivney, Crews, Hirata, Axelrod, \& Siraganian, 1981) of the transformed RBL-1 rat MC line (Eccleston, Leonard, Lowe, \& Welford, 1973) allowed investigators to deduce the mechanisms at the molecular level by which these cells participate in IgE-dependent reactions. More recent studies revealed that MCs are involved in many non-IgE-dependent processes. In that regard, some populations of mouse and human MCs can be induced to degranulate by thrombin via protease-activated receptor-1 (Par-1) (Razin \& Marx, 1984; Vliagoftis, 2002), by IgG complexes via Fc $\gamma$ RIIa or Fc $\gamma$ RIIIa (Malbec \& Daeron, 2007), by ATP via P2X, P2Y, and adenosine receptors (Forsythe \& Ennis, 1999; Kurashima et al., 2012; Sudo et al., 1996), and by complement-derived anaphylatoxins via the C3a and C5a receptors (el Lati, Dahinden, \& Church, 1994; Erdei \& Pecht, 1996) (Fig. 6.2). MCs express numerous Toll-like receptors (TLRs). While some 
populations of mouse and human MCs that have been examined so far do not degranulate when exposed to the TLR ligand lipopolysaccharide (LPS), the treated cells release numerous proinflammatory cytokines and chemokines (Matsushima, Yamada, Matsue, \& Shimada, 2004; McCurdy, Olynych, Maher, \& Marshall, 2003). Whether or not MCs are active participants in the inflammation, proliferation, and/or remodeling stages of wound healing remains an area of investigation. In this review, we present recent literature that details the diverse functions of MCs and their protease mediators that help orchestrate this complex process.

\section{DEVELOPMENT OF MCS}

MCs originate from the $\mathrm{CD} 34^{+}$pluripotent stem cells in the bone marrow and fetal liver (Arinobu et al., 2005; Kirshenbaum, Kessler, Goff, \& Metcalfe, 1991; Kitamura, Shimada, \& Go, 1979; Kitamura, Shimada, Hatanaka, \& Miyano, 1977) (Fig. 6.1A). After exiting those compartments, the committed progenitors home to virtually every organ in the body (Fig. 6.1B). The number of MC-committed progenitors in the mouse is highest in the gut mucosa (Crapper \& Schrader, 1983), presumably so that the mouse can quickly expand the number of MCs in the jejunum to combat helminth and bacterial infections. In support of this conclusion, the ability to expel the nematode Trichinella spiralis from the jejunum is delayed in infected mice lacking the chymase mMCP-1 (Knight, Wright, Lawrence, Paterson, \& Miller, 2000).

In vivo-differentiated MCs are heterogeneous, and several polarized subsets have been identified in rodents and humans. These subsets were initially distinguished in rats histochemically (Enerback, 1966), ultrastructurally (Enerback \& Lundin, 1974; Friend et al., 1996), and biochemically, based on their expression of different protease-serglycin proteoglycan (SGPG) complexes in their granules (Le Trong, Parmelee, Walsh, Neurath, \& Woodbury, 1987; Stevens et al., 1986; Woodbury et al., 1978; Yurt, Leid, \& Austen, 1977), as well as by their ability to generate varied types of eicosanoids (Heavey et al., 1988; Lewis et al., 1982), cytokines, and chemokines (Fig. 6.2).

MCs undergo the final stages of differentiation and maturation in their target tissues (Fig. 6.1B). These processes are controlled in tissue-specific manners, resulting in distinct phenotypes in different tissues (Friend et al., 1998; Gurish et al., 1995; Nakano et al., 1985; Xing, Austen, Gurish, \& Jones, 2011). The greatest numbers of mature MCs are present in the tongue, skin, and respiratory and gastrointestinal tracts (Kube, Audige, Kuther, \& Welle, 1998), which are at the interfaces of the host and external environments. The MCs in mice, rats, and humans are heterogeneous cells, and the varied tissue microenvironments where they reside ultimately determine the phenotypes, and thereby functions, of these cells during their life spans (Gurish et al., 1995; Kanakura et al., 1988; Nakano, Kanakura, Asai, \& Kitamura, 1987; Nakano et al., 1985; Otsu et al., 1987; Sonoda et al., 1986; Xing et al., 2011).

Although constitutive heparin ${ }^{+}$MCs are long-lived cells in tissues (Padawer, 1974), they and other populations of in vivo- and in vitro-differentiated MCs can reversibly alter their phenotypes, especially which types of SGPGs and enzymatically active proteases they store 
in their secretory granules (Friend et al., 1996, 1998; Ghildyal, Friend, Nicodemus, Austen, \& Stevens, 1993; Gurish et al., 1995; Sonoda et al., 1986; Stevens \& Austen, 1982). The mature MCs in the rat peritoneum contain SGPGs that preferentially have heparin glycosaminoglycans (GAGs) (Yurt et al., 1977), whereas the mature MCs in the jejunum of helminth-infected rats have SGPGs that preferentially have chondroitin sulfate-diB/E GAGs (Enerback, Kolset, Kusche, Hjerpe, \& Lindahl, 1985; Stevens et al., 1986). The first demonstration that a mature MC could reversibly alter what types of mediators it stores in its secretory granules occurred in 1982 when Stevens and Austen showed that purified rat peritoneal MCs could be induced to rapidly switch their biosynthesis of heparin to chondroitin sulfate $\mathrm{E}$ when exposed to $p$-nitrophenyl- $\beta$-D-xyloside (Stevens \& Austen, 1982).

Polarized subsets of MCs exist in mice, rats, and humans, but in situ hybridization studies revealed that even a histochemically identical population of MCs can differ substantially at the individual cell level in terms of what cytokine transcripts they express when activated via their high-affinity IgE receptors (Gurish et al., 1991). Because of the substantial plasticity in their development and the heterogeneous nature of mediator generation when activated via different mechanisms, it is possible that no two MCs in a mouse or human are identical.

In normal skin, fully developed MCs are preferentially found in the dermis and hypodermis. Maturation of MCs and their ability to exocytose their varied mediators depend on the cell's expression of numerous receptors which can respond to the diverse range of factors and pathogens that these cells encounter (Moon et al., 2010). IL-1 $\beta$, IL-3, IL-4, IL-6, IL-9, IL-10, IL-33, nerve growth factor, substance $P$, transforming growth factor- $\beta$ (TGF- $\beta$ ), kit ligand (Kitlg)/stem cell factor, glucocorticoids, and interferons are some of the many endogenous factors that regulate the development and function of mouse and human MCs (Fig. 6.1B).

In regard to the trafficking and homing of MC-committed progenitors into various tissues, Gurish and colleagues demonstrated that the presence of these precursor cells in the intestine of the mouse was dependent on the expression of the a $4 \beta 7$ integrin and the chemokine receptor Cxcr2 on the surface of the MC progenitor (Abonia et al., 2005; Gurish et al., 2001). The expression of Madcam1 and Vcam1 on the intestinal endothelium also was critical for cellular recruitment. In contrast, the inflammation-induced trafficking of MCcommitted progenitors into the lung required the expression of the $\alpha 4 \beta 7$ and $\alpha 4 \beta 1$ integrins, as well as the activation of $\mathrm{Ccr} 2 / \mathrm{Ccl} 2$ signaling pathways (Abonia et al., 2006; Collington et al., 2010; Hallgren et al., 2007). MCs and their progenitors also use the $\alpha 4 \beta 1$, $\alpha 5 \beta 1$, and a6 $\beta 1$ integrins to adhere to laminin- and fibronectin-rich extracellular matrices (ECMs) (Fehlner-Gardiner, Uniyal, von Ballestrem, \& Chan, 1996; Fehlner-Gardiner, Uniyal, von Ballestrem, Dougherty, \& Chan, 1996). Aside from those in the intestine and lung, other cytokines (e.g., TGF- $\beta$ ) and chemokines (e.g., Rantes/Ccl5 (Fig. 6.1B) and eotaxin/Ccl11) were found to be important in the recruitment and accumulation of MC-committed progenitors in the skin and other tissues. The movement of senescent mature MCs from a tissue, as occurs in the jejunum in the recovery phase of a helminth infection (Friend, Gurish, Austen, Hunt, \& Stevens, 2000), to the draining lymph nodes and then the spleen is 
likely to be dependent on some of these same chemokines and their receptors. Senescent MCs undergo nuclear segmentation during their translocation via the blood to the spleen when they have outlived their usefulness, as occurs in the recovery phase of a helminth infection (Friend et al., 2000). Because normal peripheral blood basophils are histamine ${ }^{+} /$ $\mathrm{Fc}_{\mathrm{R}} \mathrm{RI}^{+}$granulocytes that have a segmented nucleus, senescent MCs sometimes have been mistaken as basophils.

Besides integrins, cell adhesion molecule-1 (Cadm1)/SgIGSF is a plasma membrane protein that MCs and their progenitors also use to adhere to fibroblasts and other mesenchymal cells (Ito et al., 2003). Of equal importance is the tyrosine kinase receptor Kit/CD117 on the surface of MCs (Geissler, Ryan, \& Housman, 1988) which recognizes Kitlg on the plasma membrane of fibroblasts and other mesenchymal cells (Flanagan \& Leder, 1990; Martin et al., 1990). Ligand binding to Kit leads to receptor dimerization and autophosphorylation which, in turn, leads to the activation of micropthalmia transcription factor (Mitf) and other downstream intracellular proteins that are necessary for maintaining the viability, development, proliferation, and function of MCs (Galli, Zsebo, \& Geissler, 1994; Ronnstrand, 2004; Tsai et al., 1991). Mitf is particularly important in the transcription of the genes that encode a number of the serine proteases stored in the secretory granules of MCs (Funaba et al., 2003; Jippo et al., 1999; Morii et al., 1996, 1997; Murakami, Ikeda, Ogawa, \& Funaba, 2003), as are PU.1, c-jun, and the GATA family of transcription factors (Kim \& Lee, 2004; Walsh et al., 2002; Zon et al., 1991). Thus, Kitlg-defective $\mathrm{WCB} \mathrm{F}_{1} / \mathrm{J}-\mathrm{Kit}^{\mathrm{Sl}}$ / $K i t^{S l-d}$ and Kit-defective WBB6F ${ }_{1}-K_{i t}{ }^{W} / K_{i t}{ }^{W-v}\left(K i t^{W / W-v}\right)$ and C57BL/6-Kit ${ }^{W-s h}$ mice constitutively have markedly reduced numbers of protease-rich MCs in their tissues (Kitamura, Go, \& Hatanaka, 1978; Tsai, Grimbaldeston, \& Galli, 2011; Wolters et al., 2005), as do $\mathrm{mi} / \mathrm{mi}$ mice that produce an abnormal isoform of Mitf (Ebi et al., 1990). The demonstration that the MC deficiency in the stomach (Sonoda et al., 1986) and peritoneal cavity (Nakano et al., 1985, 1987; Otsu et al., 1987) of the adult Kit ${ }^{\mathrm{W} / \mathrm{W}-\mathrm{v}}$ mouse could be corrected, in part, by the adoptive transfer of in vitro-differentiated mBMMCs developed from histocompatible $\mathrm{Kit}^{+}$mice allowed investigators new opportunities to better understand the importance of protease-rich MCs in a living animal. Numerous transformed mouse-, rat-, and human-cultured MC lines were found to have an activating gain-of-function mutation in a portion of the Kit gene that encodes the intracellular domain of this tyrosine kinase receptor (Tsujimura et al., 1995). The significance of this cytokine receptor in the development of human MCs was conclusively shown in the 1990s when it was discovered that most patients with systemic mastocytosis have a comparable mutation in their KIT gene (Longley et al., 1996; Nagata, Okada, Worobec, Semere, \& Metcalfe, 1997).

Although Kitlg/Kit/Mitf-signaling pathways play vital roles in the survival and expansion of mouse MCs and their progenitors in tissues and in the expression of their granule proteases, other surface receptors are required for MCs to develop into their varied polarized subsets. For example, $\mathrm{Kit}^{\mathrm{W} / \mathrm{W}-\mathrm{v}}$ mice have increased numbers of MCs in their tissues when the T-cell cytokine IL-3 is present in abundance, as occurs in idiopathic chronic dermatitis (Galli, Arizono, Murakami, Dvorak, \& Fox, 1987), due to the fact that IL-3/ IL-3Ra- and Kitlg/Kitdependent signaling pathways in MC-committed progenitors are similar (Welham \& Schrader, 1992). Immature mBMMCs also undergo further differentiation and granule 
maturation when they encounter IL-9 (Eklund, Ghildyal, Austen, \& Stevens, 1993), IL-10 (Ghildyal et al., 1993), or fibroblasts (Levi-Schaffer, Austen, Gravallese, \& Stevens, 1986; Levi-Schaffer et al., 1987). Initially, it was thought that the ability of fibroblasts to induce granule maturation was solely due to its expression of Kitlg. Kitlg is required for the early stages of MC differentiation, and this cytokine is needed to maintain the viability of mBMMCs in culture medium lacking IL-3 (Galli et al., 1994). Nevertheless, exposure of IL-3-developed mBMMCs to recombinant Kitlg alone did not lead to granule maturation in vitro (Gurish et al., 1992). The key fibroblast-derived factor required for that process in the mouse is IL-33 which recognizes the receptor ST-2/IL1RL1 on the surface of the immature MC (Kaieda et al., 2010) (Fig. 6.1B).

MCs also can respond to inhibitory signals that are controlled by CD200 (Zhang, Cherwinski, Sedgwick, \& Phillips, 2004; Zhang \& Phillips, 2006), Lilrb4/gp49B1 (Katz et al., 1996), Fc $\gamma$ RIIb (Malbec, Fridman, \& Daeron, 1999), and IRp60/CD300a (Bachelet, Munitz, Moretta, Moretta, \& Levi-Schaffer, 2005). Hence, the development and functional responses of a protease-rich MC in any particular situation, such as a wound, are regulated in complex ways which must be evaluated in the context of both the stimulatory and inhibitory factors present in the tissue at that time.

\section{SECRETORY GRANULE PROTEASES OF HUMAN AND MOUSE MCs}

The neutral proteases that reside in the secretory granules constitute $\sim 50 \%$ of the total protein content of a mature, in vivo-differentiated connective tissue $\mathrm{MC}$ in all examined species. Mouse MCs express different combinations of mMCP-1 to -11, transmembrane tryptase/tryptase- $\gamma /$ protease serine member S (Prss) 31, cathepsin G, granzyme B, neuropsin/ Prss19, and carboxypeptidase A3 (Cpa3) (Table 6.1) (Chu, Johnson, \& Musich, 1992; Hunt et al., 1997; Lützelschwab, Huang, Kullberg, Aveskogh, \& Hellman, 1998; McNeil et al., 1991, 1992; Reynolds, Gurley, Austen, \& Serafin, 1991; Reynolds, Stevens, et al., 1989; Serafin et al., 1990, 1991; Trong et al., 1989; Wong et al., 1999; Wong, Yang, Yasuda, Li, \& Stevens, 2003; Wong, Yasuda, Morokawa, Li, \& Stevens, 2004). Most, if not all, of these 16 neutral proteases are packaged in the cell's acidic granules ionically bound to heparin(Forsberg et al., 1999; Humphries et al., 1999) or chondroitin sulfate E/diB- (Enerback et al., 1985; Razin, Stevens, Akiyama, Schmid, \& Austen, 1982; Stevens et al., 1986) bearing SGPGs (Abrink, Grujic, \& Pejler, 2004; Stevens, Nicodemus, \& Avraham, 1990).

When MCs are activated, the majority of their exocytosed protease-SGPG macromolecular complexes remain intact in the ECM for hours (Ghildyal et al., 1996) (Fig. 6.3). Due to their large size, most of these macromolecular complexes are retained near the degranulated MC, thereby limiting their biological effects to the local microenvironment. The exceptions in the mouse are the chymase mMCP-1 (Wastling, Scudamore, Thornton, Newlands, \& Miller, 1997) and the tryptase mMCP-7 (Ghildyal et al., 1996). Because the binding of these two granule proteases to SGPGs is weak at neutral $\mathrm{pH}$, small amounts of these proteases can reach the circulation when they are exocytosed from activated tissue MCs. Prss31 (Caughey et al., 2000; Wong et al., 1999) is another exception due to its novel C-terminal membranespanning domain. This tryptase is preferentially retained at the outer leaflet of the plasma 
membrane of the degranulated MCs, thereby allowing Prss31 to regulate those cell types which MCs physically contact and interact (Wong et al., 2002).

The hTryptase- $\beta$ family of tetramer-forming serine proteases, which are derived from the homologous TPSAB1 and TPSB2 genes on human chromosome 16p13.3 (Table 6.1), are the major neutral proteases present in human MCs (Miller, Moxley, \& Schwartz, 1990; Pallaoro, Fejzo, Shayesteh, Blount, \& Caughey, 1999; Schwartz, Lewis, \& Austen, 1981; Vanderslice et al., 1990). While the homologous TPSD1 gene is also present on human chromosome 16p13.3 (Pallaoro et al., 1999), the last exon of this gene has a premature translation-termination codon which causes the expression of a truncated tryptase that has greatly reduced enzymatic activity. Numerous point mutations in the human TPSAB1 and TPSB2 genes have been identified in recent years by the Human Genome Consortium that result in the expression of $>25$ different protein isoforms of each tetramer-forming enzyme. Because the functional significance of these allelic isoforms has not been deduced experimentally, investigators generally refer to the enzymatically active products of the human TPSAB 1 and TPSB 2 genes collectively as hTryptase- $\beta$. Complicating the situation in humans, novel isoforms of hTryptase- $\beta$ have been identified that are the result of differential splicing of their precursor transcripts ( Jackson et al., 2008). Studies carried out in the 1980s and 1990s used native hTryptase- $\beta$ purified from pooled skin and/or lung biopsies. It is now known that those preparations contained numerous functionally distinct enzymes derived from polymorphic genes and differentially spliced transcripts. It is therefore difficult to interpret the data reported in many of those earlier studies, even if one assumes that the preparations were not contaminated with other biologically active factors (e.g., the tryptases Prss22 (Wong et al., 2001) and Prss31 (Caughey et al., 2000; Wong et al., 2002)).

However, human MCs also store other mediators in their secretory granules ionically bound to SGPGs. As occurs in mouse MCs, the presence of these mediators can differ considerably. For example, the hTryptase- $\beta^{+}$MCs in human skin often contain substantial amounts of PRSS31 (Caughey et al., 2000; Wong et al., 1999), CPA3 (Reynolds, Gurley, et al., 1989), and the chromosome 14q11.2 family members cathepsin G (Schechter et al., 1990), granzyme B (Strik et al., 2007), and chymase-1 (CMA1) (Caughey, Zerweck, \& Vanderslice, 1991; Urata et al., 1991). As occurs in mice, the neutral proteases present in human MCs are highly restricted, and only 15 and 4 of the >8.7 million ESTs in the current database originated from the respective PRSS31 (Caughey et al., 2000; Wong et al., 1999) and CMA1 (Caughey et al., 1991) genes (see GenBank UniGene Hs.592076 and Hs. 135626). In support of these EST data, the levels of the PRSS31 and CMA1 transcripts are below detection in normal peripheral blood histamine ${ }^{+} / \mathrm{Fc}_{\mathrm{R}} \mathrm{RI}^{+}$human basophils (see microarray data at http://www.nch.go.jp/imal/GeneChip/public.htm).

The primordial gene that gave rise to the human CMA1 gene expanded in mice to give rise to the eight genes on mouse chromosome 14C3 that encode mMCP-1 (Trong et al., 1989), mMCP-2 (Serafin et al., 1990), mMCP-3/L (Serafin et al., 1991), mMCP-4 (Serafin et al., 1991), mMCP-5 (McNeil et al., 1991), mMCP-8 (Lützelschwab et al., 1998), mMCP-9 (Hunt et al., 1997), and mMCP-10/Cma2 (Chu et al., 1992). Because a similar situation occurs in rats (Lützelschwab, Pejler, Aveskogh, \& Hellman, 1997), the expansion of the serine protease gene complex on chromosome $14 \mathrm{C} 3$ took place prior to the evolutionary 
divergence of rats and mice. The Human and Mouse Genome Consortiums concluded that the mouse ortholog of human CMA1 is mMCP- 5 due to the highest degrees of similarities of their genes and translated products. In support of that conclusion, CMA1 and CPA3 are almost always coexpressed in human MCs, as occurs for mMCP-5 and Cpa3 in mouse MCs. Moreover, targeted inactivation of the $m M C P-5$ gene adversely impacts the storage of Cpa3 protein in mouse MCs and vice versa. Nevertheless, the substrate preference of mMCP-4 is more similar to that of human CMA1 (Andersson, Karlson, \& Hellman, 2008; Kunori et al., 2002). Thus, most studies carried out on mice that have attempted to obtain insight into the function of human CMA1 in inflammation and wound healing have used transgenic animals that lack mMCP-4 or mMCP-5.

The biologically active proteins that are most critical to our existence are regulated at multiple levels. There are no proteins in the body that are more tightly regulated than the MC's serine proteases. Numerous studies revealed that epigenetic, transcriptional, posttranscriptional, translational, and post-translational mechanisms are used to control the expression, activation, and granule storage of the MC's proteases in defined molar amounts. For example, even though the genes that encode mMCP-1, mMCP-2, and mMCP-4 are transcribed in IL-3-developed mBMMCs, the levels of their transcripts are below detection by blot analysis because of a cytokine- and glucocorticoid-regulated posttranscriptional mechanism that dominantly controls their stability (Eklund et al., 1997; Xia, Ghildyal, Austen, \& Stevens, 1996). Outside of the activated MC, the levels of the cell's exocytosed proteases and their enzymatic activities are controlled by protease inhibitors (Itoh, Ide, Ishikawa, \& Nawa, 1994; Pemberton, Huntley, \& Miller, 1998; Pemberton, Wright, Knight, \& Miller, 2006; Wong et al., 2002) and the ability of bystander macrophages, fibroblasts, and endothelial cells in tissues to endocytose the MC-derived protease-heparin SGPG complexes and destroy them in their primary lysosomes (Atkins, Friedman, \& Metcalfe, 1985; Atkins \& Metcalfe, 1983; Fabian, Bleiberg, \& Aronson, 1978). Thus, varied mechanisms are used in the different tissue environments to control the half-lives and tissue retention of the exocytosed protease-SGPG complexes.

Human MCs were initially classified as $\mathrm{MC}_{\mathrm{T}}$ or $\mathrm{MC}_{\mathrm{TC}}$ by Schwartz and his coworkers (Irani, Schechter, Craig, DeBlois, \& Schwartz, 1986) based on whether or not they contained detectable amounts of CMA1 in their secretory granules. This simplistic subset classification is rarely used today because it led to the erroneous conclusion that there were only two subsets of MCs in humans and that these phenotypically different populations of MCs originated from distinct progenitors. For example, it is now known that some heparin ${ }^{+} /$ tryptase ${ }^{+} / \mathrm{CMA} 1^{+}$human MCs store substantial amounts of CPA3 in their granules (Irani, Goldstein, Wintroub, Bradford, \& Schwartz, 1991), whereas others do not (Abonia et al., 2010), even though all MCs originate from a common progenitor. We now appreciate that, like what occurs in the mouse, different populations of human MCs can vary considerably in terms of the number and types of mediators they produce when activated. Thus, one of the major challenges is to understand how tissues and cells orchestrate appropriate biological responses to so many MC-derived biologically active factors.

MCs use an extensive array of surface and intracellular receptors to react to changes in their tissue microenvironments. Triggering of these receptors often leads to degranulation, which 
is characterized by the extrusion of the contents of the cell's cytoplasmic protease-rich granules (Rivera \& Gilfillan, 2006) (Figs. 6.2 and 6.3) which can have both beneficial and adverse consequences. FceRI is the main receptor on the surface of MCs that binds IgE (Kinet, 1999; Metzger, Goetze, Kanellopoulos, Holowka, \& Fewtrell, 1982). Antigen crosslinking of this receptor-bound immunoglobulin leads to activation of signaling pathways that are the primary cause of MC-dependent hypersensitivity reactions in vivo (Kraft \& Kinet, 2007), including life-threatening systemic anaphylaxis. MCs also can be activated via non-FceRI mechanisms. In those situations, the exocytosed mediators promote tumorigenesis (Chang et al., 2011; Sinnamon et al., 2008), arthritis (Lee et al., 2002; McNeil et al., 2008; Pimentel, Sampaio, D’Acquisto, Perretti, \& Oliani, 2011; Shin et al., 2009), colitis/inflammatory bowel disease (Hamilton et al., 2011), autoimmune disease (Christy \& Brown, 2007), heart disease (Kovanen, 2007; Sun et al., 2007, 2009; Zhang et al., 2011), and even cigarette smoke-induced chronic obstructive pulmonary disease (COPD; Beckett et al., 2013).

Despite their adverse roles in many inflammatory diseases, MCs and their exocytosed proteases have beneficial roles in bacterial (Huang et al., 2001; Thakurdas et al., 2007), helminth (Knight et al., 2000; Pennock \& Grencis, 2006; Shin et al., 2008), and pneumovirus infections (Ptaschinski and Foster, unpublished findings). Human MCs and their progenitors express the HIV-1 coreceptors CD4, CCR3, CCR5, and CXCL-4, and therefore are susceptible to M-tropic strains of the retrovirus (Bannert et al., 2001; Li et al., 2001; Taub et al., 2004). Considering the importance of the tetramer-forming tryptases in innate and acquired immunity, the HIV-1 infection of MCs and their progenitors is now believed to be a contributing factor in the inability of AIDS patients to combat opportunistic infections efficiently.

\section{MC INVOLVEMENT IN WOUND HEALING}

Wound healing conventionally has been divided into three stages that have been designated as the inflammation phase, proliferation phase, and maturation/remodeling phases (Schilling, 1976) (Fig. 6.4). Growing evidence has implicated MCs and their protease mediators in all three aspects of the wound-repair process ( $\mathrm{Ng}$, 2010; Nishikori et al., 1998; Noli \& Miolo, 2001, 2010; Younan et al., 2010).

\subsection{Inflammation phase}

Two to eight percent of the cells in healthy skin are mature MCs. They are located in both the hypodermis and the dermis in the vicinity of nerves, hair follicles, and blood vessels (Weber, Knop, \& Maurer, 2003) (Fig. 6.3), and are activated following tissue injury (el Sayed \& Dyson, 1993). The exocytosis of their granule mediators is an early step of the wound-induced inflammatory cascade, as evidenced by the decreased staining intensity of the protease-SGPG complexes in the cell's secretory granules $24 \mathrm{~h}$ after wound initiation. Those MCs in close proximity to the site of the tissue injury underwent more extensive degranulation (Weller, Foitzik, Paus, Syska, \& Maurer, 2006) (Fig. 6.3).

Activated MCs release mediators that can induce bystander cells to increase their expression of Kitlg, IL-3, IL-33, and other factors which then regulate MCs by feedback-loop 
mechanisms (Fig 6.1B). This situation ultimately affects the viability and function of MCs and their progenitors at the site of injury (Baghestanian et al., 1997; Metcalfe et al., 1997). The increased numbers of MCs in and around a wound could be due, in part, to the local differentiation of nongranulated progenitors. However, studies suggest that the increase in the number of MCs at the site of a wound is primarily due to the migration of mature MCs from nearby connective tissues. Not only do these MCs lack the Mki67 antigen that is expressed in proliferating cells (Trautmann, Toksoy, Engelhardt, Brocker, \& Gillitzer, 2000), they are fully granulated (Ghildyal et al., 1993). In support of this conclusion, injection of the chemokine Ccl5 into the muscle of a WT mouse (but not an MC-deficient $\mathrm{Kit}^{\mathrm{W} / \mathrm{W}-\mathrm{v}}$ mouse) resulted in the rapid accumulation of mature MCs at the site of instillation (Conti, Reale, Barbacane, Letourneau, \& Theoharides, 1998).

The thrombin-dependent conversion of fibrinogen to fibrin is a crucial initial aspect of wound healing following tissue injury. Immediately after a wound has been created, the body tries to minimize bleeding and the entry of pathogens by constricting blood vessels at the site of injury and initiating the coagulation cascade. Once that occurs, there is an increase in the permeability of blood vessels surrounding the injured area to allow the perfusion of the damaged tissue with beneficial plasma-derived factors, as well as to facilitate the accumulation of effector cells like neutrophils which are needed to hinder the local growth of bacteria and other pathogens (Broughton, Janis, \& Attinger, 2006). MCs were shown to be involved in both responses due, in part, to the complement-derived anaphylatoxins C3a and C5a which can induce MC degranulation (Johnson, Hugli, \& Muller-Eberhard, 1975) and chemotaxis (Hartmann et al., 1997). The inflammatory response that occurs after a burn to the epidermis is dependent on the binding of natural $\operatorname{IgM}$ autoantibodies to newly expressed epitopes in the damaged connective tissue which then leads to complement activation (Suber, Carroll, \& Moore, 2007). It therefore is likely that natural IgM autoantibodies also participate in the healing process of surgically wounded skin.

Degranulated MCs rapidly induce vascular permeability and subsequently the accumulation of plasma-derived fibrinogen into the wounded tissue, which then leads to its thrombindependent conversion to fibrin (Mekori \& Galli, 1990) and clotting. Histamine and eicosanoids released from activated MCs are major factors affecting vascular permeability (Maekawa, Austen, \& Kanaoka, 2002). However, other MC-derived factors also have been implicated. For example, microvascular leakage occurred by an unknown mechanism when an MC tetramer-forming tryptase was injected into the skin of a guinea pig ( $\mathrm{He} \&$ Walls, 1997).

Once a clot is created at the wound as an external barrier, it is more important to prevent further accumulation of fibrin in order to avoid life-threatening thrombus formation. To that end, MCs prolong bleeding time (Kauhanen, Kovanen, Reunala, \& Lassila, 1998) and prevent the excess accumulation of fibrin and fibrin-platelet clots in the damaged skin by exocytosing their enzymatically active tryptase-heparin complexes which degrade fibrinogen before substantial amounts of this plasma protein can be converted to fibrin by thrombin (Huang et al., 1997; Prieto-Garcia et al., 2012; Thomas, Wheeless, Stack, \& Johnson, 1998). Heparin also contributes to the anticoagulation cascade by catalyzing the 
antithrombin-III-dependent inactivation of thrombin (Rosenberg, 1978). Mouse MCs express Par-1 (Razin \& Marx, 1984; Vliagoftis, 2002), and use this thrombin receptor to exocytose their fibrinogen-destroying tryptase-heparin complexes in situations where the local concentration of thrombin is unusually high. In support of these mouse data, some pediatric mastocytosis patients who have an excess of hTryptase- $\beta^{+} /$heparin $^{+} \mathrm{MCs}$ in their tissues have excessive bleeding of their skin and gastrointestinal tract (Kettelhut \& Metcalfe, 1991). Moreover, MC tryptase-null mice contained more fibrin deposits in their skin relative to WT mice $6 \mathrm{~h}$ after the two groups of IgE-sensitized animals were given antigen in a passive cutaneous anaphylaxis reaction (Prieto-Garcia et al., 2012).

Several lines of evidence suggest that the release of MC protease mediators during an inflammatory stimulus promotes the rapid accumulation of neutrophils. This was observed in the joints of mice during experimental arthritis (Lee et al., 2002; Pimentel et al., 2011) and in the skin during urticarial reactions (Nakamura et al., 2009). Although MC-deficient $\mathrm{Kit}^{\mathrm{W} / \mathrm{W}-\mathrm{v}}$ mice have fewer neutrophils in their injured skin relative to their $\mathrm{Kit}^{+}$littermates (Egozi, Ferreira, Burns, Gamelli, \& Dipietro, 2003; Weller et al., 2006), these mice constitutively have decreased numbers of the circulating granulocytes (Nigrovic et al., 2008; Zhou, Xing, Friend, Austen, \& Katz, 2007), thereby complicating data interpretation. Nevertheless, the roles of tryptase-SGPG complexes released from activated MCs dictating the accumulation of neutrophils in the tissues of Kit-sufficient mice have been firmly established. For example, the injection of nMol amounts of LPS-free mMCP-6- or hTryptase- $\beta$-heparin complexes into different tissue sites of a naïve WT or $\mathrm{Kit}^{\mathrm{W} / \mathrm{W}-\mathrm{v}}$ mouse results in the rapid recruitment of large numbers of neutrophils (Huang et al., 1998, 2001). Furthermore, the pharmacologic inactivation of mMCP-6 resulted in diminished numbers of granulocytes in the antigen-treated airways of WT mice (Oh et al., 2002).

A major problem encountered with studies carried out on MC-deficient mice (including $\mathrm{CPA} \mathrm{Cre}^{\mathrm{C}+\mathrm{mice}}$; Feyerabend et al., 2011) is that these immune cells produce numerous factors that have contrasting bioactivities (e.g., anti-inflammatory prostaglandin $\mathrm{D}_{2}$ and IL-10 versus proinflammatory mMCP-6/hTryptase- $\beta$ and tumor necrosis factor- $\alpha$ ). In addition, the release of these factors from a $\mathrm{MC}$ is controlled by a delicate balance between stimulation of the cell's activating receptors (e.g., FceRI, Fc $\gamma$ RIIa, Fc $\gamma$ RIIIa, Par-1, and C5aR1/CD88) versus stimulation of the cell's inhibitory receptors (e.g., Lilrb4, Fc $\gamma$ RIIb, CD200, and CD300a). Such counterbalancing factors and mechanisms cannot be appreciated when MC-deficient mice are used in studies. To address these deficiencies, a number of inbred C57BL/6 mouse lines have been created using homologous recombination approaches in which a single gene was disrupted in most instances. Confirming the importance of $\mathrm{MC}$ tryptases in immunity and inflammation, transgenic C57BL/6 mice that lack the tetramer-forming tryptases mMCP-6 and mMCP-7 had a diminished ability to recruit neutrophils into their bacteria-infected peritoneal cavities (Thakurdas et al., 2007), arthritic joints (McNeil et al., 2008; Shin et al., 2009), and inflamed colons (Hamilton et al., 2011) and lungs (Beckett et al., 2013) relative to WT mice.

The fact that mice and human MCs express three tryptases that have overlapping substrate specificities contributed to the lack of appreciation of these neutral proteases in different diseases. Protease redundancy is the likely reason why the adjacent TPSAB1, TPSB2, and 
PRSS31/TPSG1 genes on human chromosome 16p13.3 were not identified in numerous quantitative trait locus and genomewide association studies carried out on humans with different inflammatory diseases. The mechanisms by which MC tryptases regulate granulocyte and/or macrophage accumulation in tissues remain to be determined at the molecular level but cultured endothelial cells, synovial fibroblasts, and bone marrowderived macrophages markedly increased their expression of numerous chemokines when they briefly encountered tryptase-heparin complexes (Beckett et al., 2013; Compton, Cairns, Holgate, \& Walls, 1998; Huang et al., 1998; Shin et al., 2009). In support of these in vitro data, the levels of a number of cytokines, chemokines, and matrix metalloproteinases (MMPs) were markedly reduced in the colons and lungs of $\mathrm{mMCP}-6^{-1-} / \mathrm{mMCP}^{-1-}$ C57BL/6 mice subjected to experimental colitis (Hamilton et al., 2011) or COPD (Beckett et al., 2013), respectively.

In the early inflammatory phase of a skin wound, the ECM proteins fibronectin and type-III collagen accumulate only to then decrease in the late inflammatory phase (Broughton et al., 2006). MC-derived chymases and tetramer-forming tryptases can degrade ECMs in indirect and direct manners in preparation for the proliferation phase of wound healing $(\mathrm{Ng}, 2010)$. In this regard, one of the targets of hTryptase- $\beta$ and its related tryptases mMCP- 6 and mMCP-7 is the C terminus of the a chain of fibrinogen (Huang et al., 1997; Prieto-Garcia et al., 2012; Thomas et al., 1998).

DuBuske, Austen, Czop, and Stevens (1984) showed that fibronectin is a preferential target of an undefined serine protease present in the secretory granules of IL-3-developed mMCP-4 $-/ \mathrm{mMCP}-5^{+} / \mathrm{mMCP}-6^{+} / \mathrm{mMCP}-7^{+} / \operatorname{Prss} 31^{-}$BALB/c mBMMCs. Because mBMMCs generated from mMCP-5-null C57BL/6 mice could not degrade fibronectin in this in vitro system, the relevant enzyme is mMCP-5 (Stevens, unpublished data). Fibronectin is also susceptible to degradation by mMCP-4 (Tchougounova, Pejler, \& Abrink, 2003). The fact that the MCs that are constitutively present in normal human skin have substantial amounts of CMA1 (Schechter et al., 1994) raises the possibility that this serine protease proteolytically destroys fibronectin in the wounded skin when cutaneous MCs in humans degranulate, particularly in the late inflammation/early proliferation phase. These data suggest that some of the proteases exocytosed from activated cutaneous MCs alter integrin-dependent signaling pathways in tissues.

Finally, MC proteases can contribute to the inflammation phase by activating tissue-resident macrophages (Chen et al., 2002; Rodgers \& Xiong, 1997). In this regard, in vitrodifferentiated mouse macrophages markedly increased their expression of Cxcl1, IL-1 $\beta$, and numerous other biologically active factors when briefly exposed to tryptase-heparin complexes (Beckett et al., 2013). In an experimental COPD model, mMCP-6 and mMCP-7 played prominent roles in the accumulation of macrophages, which is the major destructive cell in the disease. The importance of Prss31 in inflammation and wound-repair mechanisms has not been investigated in depth but the cigarette smoke-induced accumulation of macrophages in the diseased lungs also was significantly reduced in Prss31-null C57BL/6 mice (Hansbro and Stevens, unpublished observation). Prss31 is highly susceptible to inactivation by a 1-antitrypsin (A1AT)/SERPINA1 (Wong et al., 2002). In support of the finding that Prss31 participates in experimental COPD in mice, humans that are deficient in 
A1AT are at an increased risk of developing emphysema (Cohen et al., 1977). The latter data emphasize the importance of obtaining a better understanding of the factors and mechanisms that result in the inactivation and clearance of the serine proteases exocytosed from activated MCs in the lung, skin, and other tissues.

\subsection{Proliferation phase}

This aspect of wound healing is distinguished by the formation of granulation tissue, which involves fibroblast proliferation, angiogenesis, re-epithelialization, and increased deposition of type-I collagen in the ECM (Broughton et al., 2006). Here, MCs likely play critical roles by promoting the migration and proliferation of fibroblasts (Fig 6.1B), as was shown in an in vitro model (Kupietzky \& Levi-Schaffer, 1996; Levi-Schaffer \& Kupietzky, 1990). In this regard, exposure of cultured fibroblasts to increasing amounts of a MC chymase led to a dose-dependent increase in cellular proliferation (Dong, Chen, Zhang, \& Cen, 2012). Similarly, treating dermal fibroblasts with a hTryptase- $\beta$-heparin complex isolated from human lung led to a dose-dependent increase in the number of fibroblasts, as well as the accumulation of type-1 collagen (Abe, Kurosawa, Ishikawa, Miyachi, \& Kido, 1998). Similar results were obtained when fibroblasts encountered histamine (Hatamochi, Fujiwara, \& Ueki, 1985; Hatamochi, Ueki, Mauch, \& Krieg, 1991; Russel, Russell, \& Trupin, 1977). Activated MCs also release basic fibroblast growth factor (Qu et al., 1998) which is a cytokine that promotes the proliferation of fibroblasts. Thus, MCs release numerous factors that synergistically affect the fibroblasts and other cell types in the wound to ultimately promote tissue repair.

The proximity between MCs and endothelial cells that line blood vessels facilitated the interactions between the two cell types and their production of various mediators. The impact of MCs on the vasculature supports a prominent role for these granulocytes. Angiogenesis is increased in mice that have been given the MC-degranulating agent compound 48/80 ( Jakobsson, 1994; Norrby, Jakobsson, \& Sorbo, 1986), and several of the mediators exocytosed from activated MCs promote angiogenesis. While heparin is required for the accumulation of many of the proteases in the MC's granules (Forsberg et al., 1999; Humphries et al., 1999), this GAG also promotes the migration of endothelial cells (Azizkhan, Azizkhan, Zetter, \& Folkman, 1980) and vascular growth (Norrby \& Sorbo, 1992), which can be reversed by the administration of the heparin antagonist protamine sulfate ( Jakobsson, Sorbo, \& Norrby, 1990). A similar vascular response was demonstrated with a MC chymase in a granulation-tissue model carried out on hamsters (Muramatsu, Katada, Hattori, Hayashi, \& Majima, 2000). MC-derived proteases also contribute to angiogenesis by proteolytically destroying the ECM.

MCs have been associated with re-epithelialization and keratinization in several models. For example, they are modulators of hair-follicle cycling (Maurer et al., 1997). Consistent with this observation, $\mathrm{Kit}^{\mathrm{W} / \mathrm{W}-\mathrm{v}}$ mice have deficiencies in their hair-growth cycles (Maurer et al., 1997). Hair follicles are keratinocytic structures that are a part of the epithelial barrier. They are rich in stem cells, and they play significant roles in re-epithelialization during wound healing because they are a source of epithelial cells. Some of the mediators released from activated MCs can induce keratinocyte proliferation in the wounded skin, thereby inducing 
re-epithelialization that begins at the edges of the wound. Histamine, IL-1a, $-1 \beta,-6$, and tryptase-heparin complexes are MC-derived mediators that can affect epithelial cells, including their proliferation (Cairns \& Walls, 1996; Gschwandtner et al., 2008; Katayama, Yokozeki, \& Nishioka, 1992).

\subsection{Maturation/remodeling phase}

At the end of the proliferation phase and at the start of the maturation/remodeling phase, fibroblasts differentiate into myofibroblasts which are distinguished by the expression of asmooth muscle actin (Moulin et al., 1998). In normal wound healing, this is usually a transient process important in the contraction and closure of the wound. MCs have been implicated in this process as well. For example, exposure of fibroblasts to the HMC-1 MC line resulted in increased expression of a-smooth muscle actin and increased fibroblastdriven contraction of a collagen gel (Gailit, Marchese, Kew, \& Gruber, 2001). Histamine and tryptase partly mediate the latter process, as their addition to fibroblasts cultured in a collagen matrix also led to contraction. Yamamoto, Hartmann, Eckes, and Krieg (2000) concluded that the interaction of Kitlg on the surface of fibroblasts with Kit on the surface of MCs is needed for optimal gel contraction, as the addition of antibodies against either protein resulted in an $\sim 70 \%$ reduction of this process. Moyer, Saggers, and Ehrlich (2004) reported the existence of a heterotypic gap junction between the two cell types, and these investigators found that exposure of the cocultured cells to a fatty acid amide hydrolase inhibitor led to diminished lattice contraction. Although these studies differ in explaining the primary mechanism as to how MCs and fibroblasts interact in wounded skin, they agree that both cell types must be present and in direct contact in order for collagen contraction to take place efficiently.

For proper remodeling of damaged connective tissue (e.g., surgically wounded skin) to occur, a delicate balance between the degradation, synthesis, and maturation of the ECM needs to be orchestrated so that the repair of damaged skin takes place in a timely manner with minimal scarring. MC proteases can promote the degradation of ECMs and disrupt the epidermal-dermal junction (Briggaman, Schechter, Fraki, \& Lazarus, 1984) by both direct and indirect manners. In regard to the former, the hemidesmosomal transmembrane protein BP180/type XVII collagen (Lin et al., 2011) and the tight-junction protein claudin-4 (L.G. Bankova \& M.F. Gurish, unpublished data) are targets of mMCP-4. Moreover, the rat mucosal MC chymase rMCP-II alters epithelial cell monolayer permeability in association with altered distribution of the tight junction proteins ZO-1 and occludin (Scudamore, Jepson, Hirst, \& Miller, 1998). In support of these rat and mouse data, patients with bullous mastocytosis have increased numbers of degranulated MCs at the base of their subepidermal blisters (Golitz, Weston, \& Lane, 1984; Kirshenbaum, Kettelhut, Metcalfe, \& Garriga, 1989).

A number of the MC's serine proteases also can activate numerous metalloproteinase (MMP) zymogens (Lees, Taylor, \& Woolley, 1994; Lin et al., 2011; Magarinos et al., 2013). Tetramer-forming MC tryptases, for example, can activate pro-stromelysin/MMP3 which, in turn, can activate latent procollagenase (Gruber et al., 1989) to ultimately cause connective tissue remodeling. The finding that hTryptase- $\beta$ - and mMCP-6-heparin complexes can 
activate pro-MMP3 and pro-MMP13 constitutively present in femoral head cartilage explants raises the possibility that these tryptases activate other members of the "typical" family of released MMPs (namely MMP-1, $-3,-8,-10,-12,-13,-18,-19,-20,-22$, and/or -27). The substrate preference of mMCP-4 is similar to that of human CMA1, and mMCP-4 has been implicated in the activation of pro-MMP2 and pro-MMP9 (Lin et al., 2011; Tchougounova et al., 2005). Similarly, human CMA1 can degrade ECMs indirectly by activating interstitial procollagenase/MMP1 (Saarinen, Kalkkinen, Welgus, \& Kovanen, 1994). At least one MC chymase can activate latent TGF- $\beta$ (Taipale, Lohi, Saarinen, Kovanen, \& Keski-Oja, 1995; Zhao et al., 2008), which is a cytokine that counteracts the MMP-dependent degradation of the ECM. Thus, the proteases exocytosed from activated MCs in connective tissue remodeling can affect wounds in complex ways. Moreover, the complexity and redundancy outlined here further explains why the importance of MCs and their granule serine proteases in wound healing and varied inflammatory disorders were missed by quantitative trait locus and genomewide association studies.

Another event that takes place in the maturation/remodeling phase of wound healing is the crosslinking of the newly synthesized collagen that is deposited in the ECM of the repaired wound. These posttranslational modification events of collagen are the result of the lysyl oxidase-dependent modification of the protein's lysine and hydroxylysine residues. The modification of hydroxylysine results in the formation of pyridinoline, and the levels of pyridinoline are markedly increased in hypertrophic scars (Moriguchi \& Fujimoto, 1979). While the importance of MCs and their mediators in collagen maturation has not been investigated in depth, a proteomic study revealed that the levels of proly-4-hydroxylase in mouse 3T3 fibroblasts differed considerably when these mesenchymal cells were cocultured with mBMMCs generated from WT, mMCP-6-null, and mMCP-5-null C57BL/6 mice (R.L. Stevens, unpublished data). These data raise the possibility that MC granule proteases somehow influence the type and/or extent of collagen crosslinking in wounded skin in the maturation/remodeling phase of wound healing by regulating the expression of key biosynthetic enzymes in that process. In support of this conclusion, collagen accumulation in the airways of cigarette smoke-treated Prss31-null C57BL/6 mice was markedly reduced relative to that in the airways of similarly treated WT C57BL/6 mice (Hansbro, Hamilton, and Stevens, unpublished observation).

\subsection{Temporal aspects of MC activation}

Although the above evidence highlights the involvement of MCs and their protease mediators throughout the different phases of wound healing, their indispensability to the process remains a matter of debate due to the fact that most of these early studies were carried out on problematic Kit ${ }^{\mathrm{W} / \mathrm{W}-\mathrm{v}}$ mice. Comparing the effects of skin injury in MCdeficient $\mathrm{Kit}^{\mathrm{W} / \mathrm{W}-\mathrm{v}}$ mice and MC-sufficient $\mathrm{Kit}^{+}$mice, Weller and coworkers noted that the absence of protease-rich MCs led to delayed closure of 6-mm wounds of the skin (Weller et al., 2006). Even though both groups of mice had complete wound closure by day 10, the wounds of Kit ${ }^{\mathrm{W} / \mathrm{W}-\mathrm{v}}$ mice only started to decrease in size $12 \mathrm{~h}$ after injury. In a study of microdeformation wound healing in $\mathrm{Kit}^{+}$versus $\mathrm{Kit}^{\mathrm{W}} / \mathrm{W}-\mathrm{v}$ mice, the presence of MCs was associated with increased wound tissue granulation, cell proliferation, blood vessel sprouting, and collagen maturation (Younan et al., 2011). 
In contrast, other investigators were unable to detect a significant difference in wound closure between $\mathrm{Kit}^{+}$and $\mathrm{Kit}^{\mathrm{W} / \mathrm{W}-\mathrm{v}}$ mice when the rate of wound closure in punch biopsies was evaluated by histomorphometric analysis for re-epithelialization 3 days postinjury (Egozi et al., 2003). These contrasting findings highlight the temporal contribution of MCs in the repair mechanism, which is most noticeable in the acute aftermath of injury. As wound closure eventually occurred in both models, it is thought that mice have MCindependent fallback mechanisms to repair damaged connective tissue. Nevertheless, it is worthwhile to note that histological differences were found even though wound closure eventually occurred in both of the above models. In that regard, Iba and coworkers demonstrated that collagen aggregation at the wound edges was tighter and less interwoven in $\mathrm{Kit}^{\mathrm{W} / \mathrm{W}-\mathrm{v}}$ mice, as opposed to $\mathrm{Kit}^{+}$mice, 20 days after wounding (Iba, Shibata, Kato, \& Masukawa, 2004). It is anticipated that a better understanding of the importance of MCs and their specific mediators in the repair process will be obtained once follow-up studies are carried out on recently created transgenic mouse lines that lack specific MC mediators.

\subsection{MCs and pathologic healing}

Although MCs contribute to the different stages of wound healing in beneficial ways, they also can have detrimental roles, especially when they are chronically activated. In the skin, MCs have been studied in fibrotic processes that leads to scarring and the hypertrophy of scars (Kischer, Bunce, \& Shetlah, 1978). Younan and coworkers noted pronounced differences in the wound healing patterns between MC-deficient Kit ${ }^{\mathrm{W}} / \mathrm{W}-\mathrm{v}$ and MCsufficient $\mathrm{Kit}^{+}$mice when these animals received a scald burn (Younan et al., 2010). The treated $\mathrm{Kit}^{\mathrm{W} / \mathrm{W}-\mathrm{v}}$ mice showed significantly less scarring and a reappearance of more hair follicles at day 13 relative to the treated $\mathrm{Kit}^{+}$mice. Using transgenic mice, these differences were shown to be primarily due to $\mathrm{mMCP}-4$ and $\mathrm{mMCP}-5$.

Wulff and coworkers investigated wound healing in fetal mice (Wulff et al., 2012). They discovered that mice wounded at embryonic day 15 (E15) healed without scars. In contrast, those animals wounded at embryonic day 18 (E18) healed with scars. Interestingly, histologic analysis revealed fewer MCs in the dermis of the E15 mice. In support of an adverse role for an undefined preformed MC-derived mediator in the scarring process, the injection of a lysate of MCs into the E15 embryos led to scarring similar to that observed in wounded E18 mice. MC-deficient Kit ${ }^{\mathrm{W} / \mathrm{W}-\mathrm{v}}$ embryos wounded at E18 also showed significantly less scarring than MC-sufficient $\mathrm{Kit}^{+}$embryos wounded at that time point.

Keloids are benign tumor-like scars with exuberant growth; they are in vivo models of abnormal healing of wounded skin. MCs have been implicated in this process, as histology revealed increased numbers of MCs in keloids (Shaker, Ayuob, \& Hajrah, 2011). When keloids were treated with intralesional cryotherapy, improvement of the lesions was correlated with decreased numbers of MCs, as assessed histochemically (Har-Shai et al., 2011). Histamine levels were elevated in keloid lesions which may lead to the abnormal collagen crosslinking seen in such pathology (Placik \& Lewis, 1992). Nevertheless, the primary mediators exocytosed from cutaneous MCs that promote keloid development have not been identified. 
Coneely and coworkers evaluated MC degranulation in rats that had undergone surgical colon anastomosis (Coneely, Kennelly, Bouchier-Hayes, \& Winter, 2010). These investigators found that intraperitoneal administration of compound $48 / 80$ led to an increase in bursting pressure and hydroxyproline content of the hypoperfused bowel area, as well as stronger anastomosis. In a pathology-directed approach, Gallant-Behm and coworkers evaluated the effects of administering the MC stabilizer ketotifen on the contraction and fibrosis of wounded skin in two pig models (Gallant-Behm, Hildebrand, \& Hart, 2008). The Yorkshire pig was studied because it is an animal whose wounded skin heals in a manner similar to that of normal humans. The red Duroc pig was studied because this animal heals with some features of human hypertrophic scars, including the pathologic contraction of skin. Gallant-Behm and coworkers found that ketotifen treatment reduced collagen deposition and wound contraction in Duroc pigs but not in Yorkshire pigs. It therefore was concluded that preventing the release of undefined mediators from activated MCs could help in the prevention of pathologic development of wounds, while maintaining physiologic healing.

\section{CONCLUSIONS AND THERAPEUTIC DIRECTIONS}

The involvement of MCs and their serine proteases in the physiology and pathology of inflammation and wound repair identifies these immune cells and their granule constituents as intriguing targets for therapy. MCs have the ability to respond to a variety of stimuli that are important for the different phases of wound healing. Notably, the beneficial roles of MCs are lost in some conditions (e.g., chronic stimulation). Detrimental effects can occur, and this is often dependent on inappropriate cellular activation during the varied phases of tissue repair. These data suggest that the beneficial roles of MCs in tissue repair are highly dependent on the proper regulation of cellular activation, what granule proteases they express, and how much and when these proteases are released. Nevertheless, we do not yet fully understood at the molecular level how MCs and their proteases promote wound healing and hinder scar formation. Thus, further studies employing transgenic mice that lack MCspecific mediators will be invaluable in dissecting the role of the cell in the wound-repair processes. Furthermore, identifying the MC-dependent pathways that regulate the processes associated with tissue repair has substantial therapeutic implications.

\section{Acknowledgments}

We thank Professors Paul Foster (Univ. Newcastle, Newcastle, Australia) and K. Frank Austen (Harvard Med. Sch. and Brigham and Women's Hosp.) for their helpful suggestions. This work was supported by NIH grants AI059746, AI065858, AI083516, DK094971; a NHMRC project grant; and by research fellowship grants to professors R. L. S. and S. A. K. from the Harvard Club of Australia Foundation.

\section{References}

Abe M, Kurosawa M, Ishikawa O, Miyachi Y, Kido H. Mast cell tryptase stimulates both human dermal fibroblast proliferation and type I collagen production. Clinical and Experimental Allergy. 1998; 28:1509-1517. [PubMed: 10024222]

Abonia JP, Austen KF, Rollins BJ, Joshi SK, Flavell RA, Kuziel WA, et al. Constitutive homing of mast cell progenitors to the intestine depends on autologous expression of the chemokine receptor CXCR2. Blood. 2005; 105:4308-4313. [PubMed: 15705791] 
Abonia JP, Blanchard C, Butz BB, Rainey HF, Collins MH, Stringer K, et al. Involvement of mast cells in eosinophilic esophagitis. The Journal of Allergy and Clinical Immunology. 2010; 126:140149. [PubMed: 20538331]

Abonia JP, Hallgren J, Jones T, Shi T, Xu Y, Koni P, et al. a4 integrins and VCAM-1, but not MAdCAM-1, are essential for recruitment of mast cell progenitors to the inflamed lung. Blood. 2006; 108:1588-1594. [PubMed: 16670268]

Abrink M, Grujic M, Pejler G. Serglycin is essential for maturation of mast cell secretory granule. The Journal of Biological Chemistry. 2004; 279:40897-40905. [PubMed: 15231821]

Andersson MK, Karlson U, Hellman L. The extended cleavage specificity of the rodent $\beta$-chymases rMCP-1 and mMCP-4 reveal major functional similarities to the human mast cell chymase. Molecular Immunology. 2008; 45:766-775. [PubMed: 17681377]

Arinobu Y, Iwasaki H, Gurish MF, Mizuno S, Shigematsu H, Ozawa H, et al. Developmental checkpoints of the basophil/mast cell lineages in adult murine hematopoiesis. Proceedings of the National Academy of Sciences of the United States of America. 2005; 102:18105-18110. [PubMed: 16330751]

Atkins FM, Friedman MM, Metcalfe DD. Biochemical and microscopic evidence for the internalization and degradation of heparin-containing mast cell granules by bovine endothelial cells. Laboratory Investigation. 1985; 52:278-286. [PubMed: 3974200]

Atkins FM, Metcalfe DD. Degradation of the heparin matrix of mast cell granules by cultured fibroblasts. Journal of Immunology. 1983; 131:1420-1425.

Azizkhan RG, Azizkhan JC, Zetter BR, Folkman J. Mast cell heparin stimulates migration of capillary endothelial cells in vitro. The Journal of Experimental Medicine. 1980; 152:931-944. [PubMed: 7420025]

Bachelet I, Munitz A, Moretta A, Moretta L, Levi-Schaffer F. The inhibitory receptor IRp60 (CD300a) is expressed and functional on human mast cells. Journal of Immunology. 2005; 175:7989-7995.

Baghestanian M, Hofbauer R, Kress HG, Wojta J, Fabry A, Binder BR, et al. Thrombin augments vascular cell-dependent migration of human mast cells: Role of MGF. Thrombosis and Haemostasis. 1997; 77:577-584. [PubMed: 9066013]

Bannert N, Farzan M, Friend DS, Ochi H, Price KS, Sodroski J, et al. Human mast cell progenitors can be infected by macrophagetropic human immunodeficiency virus type 1 and retain virus with maturation in vitro. Journal of Virology. 2001; 75:10808-10814. [PubMed: 11602722]

Beckett EL, Stevens RL, Jarnicki AG, Kim RY, Hanish I, Hansbro NG, et al. A new short-term mouse model of chronic obstructive pulmonary disease identifies a role for mast cell tryptase in pathogenesis. The Journal of Allergy and Clinical Immunology. 2013; 131:752-762. [PubMed: 23380220]

Briggaman RA, Schechter NM, Fraki J, Lazarus GS. Degradation of the epidermal-dermal junction by proteolytic enzymes from human skin and human polymorphonuclear leukocytes. The Journal of Experimental Medicine. 1984; 160:1027-1042. [PubMed: 6384417]

Broughton G, Janis JE, Attinger CE. The basic science of wound healing. Plastic and Reconstructive Surgery. 2006; 117:12S-34S. [PubMed: 16799372]

Cairns JA, Walls AF. Mast cell tryptase is a mitogen for epithelial cells: Stimulation of IL-8 production and intercellular adhesion molecule-1 expression. Journal of Immunology. 1996; $156: 275-283$.

Caughey GH, Raymond WW, Blount JL, Hau LW, Pallaoro M, Wolters PJ, et al. Characterization of human $\gamma$ tryptases, novel members of the chromosome 16p mast cell tryptase and prostasin gene families. Journal of Immunology. 2000; 164:6566-6575.

Caughey GH, Zerweck EH, Vanderslice P. Structure, chromosomal assignment, and deduced amino acid sequence of a human gene for mast cell chymase. The Journal of Biological Chemistry. 1991; 266:12956-12963. [PubMed: 2071582]

Chang DZ, Ma Y, Ji B, Wang H, Deng D, Liu Y, et al. Mast cells in tumor microenvironment promotes the in vivo growth of pancreatic ductal adenocarcinoma. Clinical Cancer Research. 2011; 17:7015-7023. [PubMed: 21976550]

Chen R, Fairley JA, Zhao ML, Giudice GJ, Zillikens D, Diaz LA, et al. Macrophages, but not T and B lymphocytes, are critical for subepidermal blister formation in experimental bullous pemphigoid: 
Macrophage-mediated neutrophil infiltration depends on mast cell activation. Journal of Immunology. 2002; 169:3987-3992.

Christy AL, Brown MA. The multitasking mast cell: Positive and negative roles in the progression of autoimmunity. Journal of Immunology. 2007; 179:2673-2679.

Chu W, Johnson DA, Musich PR. Molecular cloning and characterization of mouse mast cell chymases. Biochimica et Biophysica Acta. 1992; 1121:83-87. [PubMed: 1376147]

Cohen BH, Ball WC Jr, Brashears S, Diamond EL, Kreiss P, Levy DA, et al. Risk factors in chronic obstructive pulmonary disease (COPD). American Journal of Epidemiology. 1977; 105:223-232. [PubMed: 300564]

Collington SJ, Hallgren J, Pease JE, Jones TG, Rollins BJ, Westwick J, et al. The role of the CCL2/ CCR2 axis in mouse mast cell migration in vitro and in vivo. Journal of Immunology. 2010; 184:6114-6123.

Compton SJ, Cairns JA, Holgate ST, Walls AF. The role of mast cell tryptase in regulating endothelial cell proliferation, cytokine release, and adhesion molecule expression: Tryptase induces expression of mRNA for IL-1 $\beta$ and IL-8 and stimulates the selective release of IL-8 from human umbilical vein endothelial cells. Journal of Immunology. 1998; 161:1939-1946.

Coneely J, Kennelly R, Bouchier-Hayes D, Winter DC. Mast cell degranulation is essential for anastomotic healing in well perfused and poorly perfused rat colon. The Journal of Surgical Research. 2010; 164:e73-e76. [PubMed: 20828736]

Conti P, Reale M, Barbacane RC, Letourneau R, Theoharides TC. Intramuscular injection of hrRANTES causes mast cell recruitment and increased transcription of histidine decarboxylase in mice: Lack of effects in genetically mast cell-deficient $W / W^{\mathrm{V}}$ mice. The FASEB Journal. 1998; 12:1693-1700.

Crapper RM, Schrader JW. Frequency of mast cell precursors in normal tissues determined by an in vitro assay: Antigen induces parallel increases in the frequency of $\mathrm{P}$ cell precursors and mast cells. Journal of Immunology. 1983; 131:923-928.

Dong X, Chen J, Zhang Y, Cen Y. Mast cell chymase promotes cell proliferation and expression of certain cytokines in a dose-dependent manner. Molecular Medicine Reports. 2012; 5:1487-1490. [PubMed: 22470087]

DuBuske L, Austen KF, Czop J, Stevens RL. Granule-associated serine neutral proteases of the mouse bone marrow-derived mast cell that degrade fibronectin: Their increase after sodium butyrate treatment of the cells. Journal of Immunology. 1984; 133:1535-1541.

Ebi Y, Kasugai T, Seino Y, Onoue H, Kanemoto T, Kitamura Y. Mechanism of mast cell deficiency in mutant mice of mi/mi genotype: An analysis by co-culture of mast cells and fibroblasts. Blood. 1990; 75:1247-1251. [PubMed: 2310824]

Eccleston E, Leonard BJ, Lowe JS, Welford HJ. Basophilic leukaemia in the albino rat and a demonstration of the basopoietin. Nature: New Biology. 1973; 244:73-76.

Egozi EI, Ferreira AM, Burns AL, Gamelli RL, Dipietro LA. Mast cells modulate the inflammatory but not the proliferative response in healing wounds. Wound Repair and Regeneration. 2003; 11:46-54. [PubMed: 12581426]

Ehrlich, P. Doctoral thesis. Germany: University of Leipzig; 1878. Beitrage zur Theorie und Praxis der Histologischen Farbung.

Eklund KK, Ghildyal N, Austen KF, Stevens RL. Induction by IL-9 and suppression by IL-3 and IL-4 of the levels of chromosome 14-derived transcripts that encode late-expressed mouse mast cell proteases. Journal of Immunology. 1993; 151:4266-4273.

Eklund KK, Humphries DE, Xia Z, Ghildyal N, Friend DS, Gross V, et al. Glucocorticoids inhibit the cytokine-induced proliferation of mast cells, the high-affinity IgE receptor-mediated expression of TNF-a, and the IL-10-induced expression of chymases. Journal of Immunology. 1997; 158:43734380.

el Lati SG, Dahinden CA, Church MK. Complement peptides C3a- and C5a-induced mediator release from dissociated human skin mast cells. The Journal of Investigative Dermatology. 1994; 102:803-806. [PubMed: 7513741]

el Sayed SO, Dyson M. Responses of dermal mast cells to injury. Journal of Anatomy. 1993; 182:369376. [PubMed: 8226292] 
Enerbäck L. Mast cells in rat gastrointestinal mucosa. 2. Dye-binding and metachromatic properties. Acta Pathologica et Microbiologica Scandinavica. 1966; 66:303-312. [PubMed: 4162018]

Enerbäck L, Kolset SO, Kusche M, Hjerpe A, Lindahl U. Glycosaminoglycans in rat mucosal mast cells. The Biochemical Journal. 1985; 227:661-668. [PubMed: 4004785]

Enerbäck L, Lundin PM. Ultrastructure of mucosal mast cells in normal and compound 48-80-treated rats. Cell and Tissue Research. 1974; 150:95-105. [PubMed: 4367865]

Erdei A, Pecht I. Complement peptides and mast cell triggering. Immunology Letters. 1996; 54:109_ 112. [PubMed: 9052863]

Fabian I, Bleiberg I, Aronson M. Increased uptake and desulphation of heparin by mouse macrophages in the presence of polycations. Biochimica et Biophysica Acta. 1978; 544:69-76. [PubMed: 718998]

Fehlner-Gardiner CC, Uniyal S, von Ballestrem CG, Chan BM. Differential utilization of VLA-4

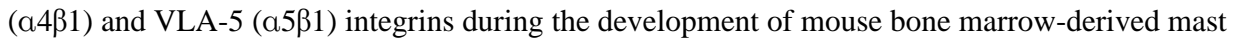
cells. Differentiation. 1996; 60:317-325. [PubMed: 8855375]

Fehlner-Gardiner C, Uniyal S, von Ballestrem C, Dougherty GJ, Chan BM. Integrin VLA-6 (a6ß1) mediates adhesion of mouse bone marrow-derived mast cells to laminin. Allergy. 1996; 51:650 656. [PubMed: 8899118]

Feyerabend TB, Weiser A, Tietz A, Stassen M, Harris N, Kopf M, et al. Cre-mediated cell ablation contests mast cell contribution in models of antibody- and T cell-mediated autoimmunity. Immunity. 2011; 35:832-844. [PubMed: 22101159]

Flanagan JG, Leder P. The kit ligand: A cell surface molecule altered in steel mutant fibroblasts. Cell. 1990; 63:185-194. [PubMed: 1698555]

Forsberg E, Pejler G, Ringvall M, Lunderius C, Tomasini-Johansson B, Kusche-Gullberg M, et al. Abnormal mast cells in mice deficient in a heparin-synthesizing enzyme. Nature. 1999; 400:773776. [PubMed: 10466727]

Forsythe P, Ennis M. Adenosine, mast cells and asthma. Inflammation Research. 1999; 48:301-307. [PubMed: 10442481]

Friend DS, Ghildyal N, Austen KF, Gurish MF, Matsumoto R, Stevens RL. Mast cells that reside at different locations in the jejunum of mice infected with Trichinella spiralis exhibit sequential changes in their granule ultrastructure and chymase phenotype. The Journal of Cell Biology. 1996; 135:279-290. [PubMed: 8858180]

Friend DS, Ghildyal N, Gurish MF, Hunt J, Hu X, Austen KF, et al. Reversible expression of tryptases and chymases in the jejunal mast cells of mice infected with Trichinella spiralis. Journal of Immunology. 1998; 160:5537-5545.

Friend DS, Gurish MF, Austen KF, Hunt J, Stevens RL. Senescent jejunal mast cells and eosinophils in the mouse preferentially translocate to the spleen and draining lymph node, respectively, during the recovery phase of helminth infection. Journal of Immunology. 2000; 165:344-352.

Funaba M, Ikeda T, Murakami M, Ogawa K, Tsuchida K, Sugino H, et al. Transcriptional activation of mouse mast cell protease- 7 by activin and transforming growth factor- $\beta$ is inhibited by microphthalmia-associated transcription factor. The Journal of Biological Chemistry. 2003; 278:52032-52041. [PubMed: 14527958]

Gailit J, Marchese MJ, Kew RR, Gruber BL. The differentiation and function of myofibroblasts is regulated by mast cell mediators. The Journal of Investigative Dermatology. 2001; 117:11131119. [PubMed: 11710921]

Gallant-Behm CL, Hildebrand KA, Hart DA. The mast cell stabilizer ketotifen prevents development of excessive skin wound contraction and fibrosis in red Duroc pigs. Wound Repair and Regeneration. 2008; 16:226-233. [PubMed: 18318808]

Galli SJ, Arizono N, Murakami T, Dvorak AM, Fox JG. Development of large numbers of mast cells at sites of idiopathic chronic dermatitis in genetically mast cell-deficient $\mathrm{WBB}_{6} \mathrm{~F}_{1}-W / W^{v}$ mice. Blood. 1987; 69:1661-1666. [PubMed: 3580572]

Galli SJ, Zsebo KM, Geissler EN. The kit ligand, stem cell factor. Advances in Immunology. 1994; 55:1-96. [PubMed: 7508174]

Geissler EN, Ryan MA, Housman DE. The dominant-white spotting (W) locus of the mouse encodes the c-kit proto-oncogene. Cell. 1988; 55:185-192. [PubMed: 2458842] 
Ghildyal N, Friend DS, Nicodemus CF, Austen KF, Stevens RL. Reversible expression of mouse mast cell protease 2 mRNA and protein in cultured mast cells exposed to IL-10. Journal of Immunology. 1993; 151:3206-3214.

Ghildyal N, Friend DS, Stevens RL, Austen KF, Huang C, Penrose JF, et al. Fate of two mast cell tryptases in V3 mastocytosis and normal BALB/c mice undergoing passive systemic anaphylaxis: Prolonged retention of exocytosed mMCP-6 in connective tissues, and rapid accumulation of enzymatically active mMCP-7 in the blood. The Journal of Experimental Medicine. 1996; 184:1061-1073. [PubMed: 9064323]

Golitz LE, Weston WL, Lane AT. Bullous mastocytosis: Diffuse cutaneous mastocytosis with extensive blisters mimicking scalded skin syndrome or erythema multiforme. Pediatric Dermatology. 1984; 1:288-294. [PubMed: 6387670]

Gruber BL, Marchese MJ, Suzuki K, Schwartz LB, Okada Y, Nagase H, et al. Synovial procollagenase activation by human mast cell tryptase dependence upon matrix metalloproteinase 3 activation. The Journal of Clinical Investigation. 1989; 84:1657-1662. [PubMed: 2553780]

Gschwandtner M, Purwar R, Wittmann M, Baumer W, Kietzmann M, Werfel T, et al. Histamine upregulates keratinocyte MMP-9 production via the histamine H1 receptor. The Journal of Investigative Dermatology. 2008; 128:2783-2791. [PubMed: 18548114]

Gu Y, Byrne MC, Paranavitana NC, Aronow B, Siefring JE, D’Souza M, et al. Rac2, a hematopoiesisspecific Rho GTPase, specifically regulates mast cell protease gene expression in bone marrowderived mast cells. Molecular and Cellular Biology. 2002; 22:7645-7657. [PubMed: 12370311]

Gurish MF, Ghildyal N, Arm J, Austen KF, Avraham S, Reynolds D, et al. Cytokine mRNAs are preferentially increased relative to secretory granule protein mRNAs in mouse bone marrowderived mast cells that have undergone IgE-mediated activation and degranulation. Journal of Immunology. 1991; 146:1527-1533.

Gurish MF, Ghildyal N, McNeil HP, Austen KF, Gillis S, Stevens RL. Differential expression of secretory granule proteases in mouse mast cells exposed to interleukin-3 and c-kit ligand. The Journal of Experimental Medicine. 1992; 175:1003-1012. [PubMed: 1372640]

Gurish MF, Pear WS, Stevens RL, Scott ML, Sokol K, Ghildyal N, et al. Tissue-regulated differentiation and maturation of a $\mathrm{v}$-abl-immortalized mast cell-committed progenitor. Immunity. 1995; 3:175-186. [PubMed: 7648391]

Gurish MF, Tao H, Abonia JP, Arya A, Friend DS, Parker CM, et al. Intestinal mast cell progenitors require CD49d $\beta 7$ ( $\mathrm{a} 4 \beta 7$ integrin) for tissue-specific homing. The Journal of Experimental Medicine. 2001; 194:1243-1252. [PubMed: 11696590]

Hallgren J, Jones TG, Abonia JP, Xing W, Humbles A, Austen KF, et al. Pulmonary CXCR2 regulates VCAM-1 and antigen-induced recruitment of mast cell progenitors. Proceedings of the National Academy of Sciences of the United States of America. 2007; 104:20478-20483. [PubMed: 18077323]

Hamilton MJ, Sinnamon MJ, Lyng GD, Glickman JN, Wang X, Xing W, et al. Essential role for mast cell tryptase in acute experimental colitis. Proceedings of the National Academy of Sciences of the United States of America. 2011; 108:290-295. [PubMed: 21173247]

Har-Shai Y, Mettanes I, Zilberstein Y, Genin O, Spector I, Pines M. Keloid histopathology after intralesional cryosurgery treatment. Journal of the European Academy of Dermatology and Venereology. 2011; 25:1027-1036. [PubMed: 21108665]

Hartmann K, Henz BM, Kruger-Krasagakes S, Kohl J, Burger R, Guhl S, et al. C3a and C5a stimulate chemotaxis of human mast cells. Blood. 1997; 89:2863-2870. [PubMed: 9108406]

Hatamochi A, Fujiwara K, Ueki H. Effects of histamine on collagen synthesis by cultured fibroblasts derived from guinea pig skin. Archives of Dermatological Research. 1985; 277:60-64. [PubMed: 3970588]

Hatamochi A, Ueki H, Mauch C, Krieg T. Effect of histamine on collagen and collagen mRNA production in human skin fibroblasts. Journal of Dermatological Science. 1991; 2:407-412. [PubMed: 1814439]

He S, Walls AF. Human mast cell tryptase: A stimulus of microvascular leakage and mast cell activation. European Journal of Pharmacology. 1997; 328:89-97. [PubMed: 9203574] 
Heavey DJ, Ernst PB, Stevens RL, Befus AD, Bienenstock J, Austen KF. Generation of leukotriene $\mathrm{C}_{4}$, leukotriene $\mathrm{B}_{4}$, and prostaglandin $\mathrm{D}_{2}$ by immuno- logically activated rat intestinal mucosa mast cells. Journal of Immunology. 1988; 140:1953-1957.

Huang C, De Sanctis GT, O'Brien PJ, Mizgerd JP, Friend DS, Drazen JM, et al. Evaluation of the substrate specificity of human mast cell tryptase $\beta 1$ and demonstration of its importance in bacterial infections of the lung. The Journal of Biological Chemistry. 2001; 276:26276-26284. [PubMed: 11335723]

Huang C, Friend DS, Qiu WT, Wong GW, Morales G, Hunt J, et al. Induction of a selective and persistent extravasation of neutrophils into the peritoneal cavity by tryptase mouse mast cell protease 6. Journal of Immunology. 1998; 160:1910-1919.

Huang C, Wong GW, Ghildyal N, Gurish MF, SŠali A, Matsumoto R, et al. The tryptase, mouse mast cell protease 7, exhibits anticoagulant activity in vivo and in vitro due to its ability to degrade fibrinogen in the presence of the diverse array of protease inhibitors in plasma. The Journal of Biological Chemistry. 1997; 272:31885-31893. [PubMed: 9395536]

Humphries DE, Wong GW, Friend DS, Gurish MF, Qiu WT, Huang C, et al. Heparin is essential for the storage of specific granule proteases in mast cells. Nature. 1999; 400:769-772. [PubMed: 10466726]

Hunt JE, Friend DS, Gurish MF, Feyfant E, SŠali A, Huang C, et al. Mouse mast cell protease 9, a novel member of the chromosome 14 family of serine proteases that is selectively expressed in uterine mast cells. The Journal of Biological Chemistry. 1997; 272:29158-29166. [PubMed: 9360993]

Iba Y, Shibata A, Kato M, Masukawa T. Possible involvement of mast cells in collagen remodeling in the late phase of cutaneous wound healing in mice. International Immunopharmacology. 2004; 4:1873-1880. [PubMed: 15531302]

Irani AM, Goldstein SM, Wintroub BU, Bradford T, Schwartz LB. Human mast cell carboxypeptidase: Selective localization to $\mathrm{MC}_{\mathrm{TC}}$ cells. Journal of Immunology. 1991; 147:247-253.

Irani AA, Schechter NM, Craig SS, DeBlois G, Schwartz LB. Two types of human mast cells that have distinct neutral protease compositions. Proceedings of the National Academy of Sciences of the United States of America. 1986; 83:4464-4468. [PubMed: 3520574]

Ishizaka K, Ishizaka T, Hornbrook MM. Physicochemical properties of human reaginic antibody IV. Presence of a unique immunoglobulin as a carrier of reaginic activity. Journal of Immunology. 1966; 97:75-85.

Ito A, Jippo T, Wakayama T, Morii E, Koma Y, Onda H, et al. SgIGSF: A new mast-cell adhesion molecule used for attachment to fibroblasts and transcriptionally regulated by MITF. Blood. 2003; 101:2601-2608. [PubMed: 12456501]

Itoh H, Ide H, Ishikawa N, Nawa Y. Mast cell protease inhibitor, trypstatin, is a fragment of inter-atrypsin inhibitor light chain. The Journal of Biological Chemistry. 1994; 269:3818-3822. [PubMed: 7508921]

Jackson NE, Wang HW, Bryant KJ, McNeil HP, Husain A, Liu K, et al. Alternate mRNA splicing in multiple human tryptase genes is predicted to regulate tetramer formation. The Journal of Biological Chemistry. 2008; 283:34178-34187. [PubMed: 18854315]

Jakobsson AE. Angiogenesis induced by mast cell secretion in rat peritoneal connective tissue is a process of three phases. Microvascular Research. 1994; 47:252-269. [PubMed: 7517492]

Jakobsson A, Sorbo J, Norrby K. Protamine and mast-cell-mediated angiogenesis in the rat. Journal of Experimental Pathology. 1990; 71:209-217. [PubMed: 1691920]

Jippo T, Lee YM, Katsu Y, Tsujino K, Morii E, Kim DK, et al. Deficient transcription of mouse mast cell protease 4 gene in mutant mice of mi/mi genotype. Blood. 1999; 93:1942-1950. [PubMed: 10068667]

Johnson AR, Hugli TE, Muller-Eberhard HJ. Release of histamine from rat mast cells by the complement peptides C3a and C5a. Immunology. 1975; 28:1067-1080. [PubMed: 48505]

Kaieda S, Shin K, Nigrovic PA, Seki K, Lee RT, Stevens RL, et al. Synovial fibroblasts promote the expression and granule accumulation of tryptase via interleukin-33 and its receptor ST-2 (IL1RL1). The Journal of Biological Chemistry. 2010; 285:21478-21486. [PubMed: 20427273] 
Kanakura Y, Thompson H, Nakano T, Yamamura T, Asai H, Kitamura Y, et al. Multiple bidirectional alterations of phenotype and changes in proliferative potential during the in vitro and in vivo passage of clonal mast cell populations derived from mouse peritoneal mast cells. Blood. 1988; 72:877-885. [PubMed: 3416076]

Katayama I, Yokozeki H, Nishioka K. Mast-cell-derived mediators induce epidermal cell proliferation: Clue for lichenified skin lesion formation in atopic dermatitis. International Archives of Allergy and Immunology. 1992; 98:410-414. [PubMed: 1422267]

Katz HR, Vivier E, Castells MC, McCormick MJ, Chambers JM, Austen KF. Mouse mast cell gp49B1 contains two immunoreceptor tyrosine-based inhibition motifs and suppresses mast cell activation when coligated with the high-affinity Fc receptor for IgE. Proceedings of the National Academy of Sciences of the United States of America. 1996; 93:10809-10814. [PubMed: 8855262]

Kauhanen P, Kovanen PT, Reunala T, Lassila R. Effects of skin mast cells on bleeding time and coagulation activation at the site of platelet plug formation. Thrombosis and Haemostasis. 1998; 79:843-847. [PubMed: 9569202]

Kettelhut BV, Metcalfe DD. Pediatric mastocytosis. The Journal of Investigative Dermatology. 1991; 96:15S-18S.

Kim DK, Lee YM. Requirement of c-jun transcription factor on the mouse mast cell protease-6 expression in the mast cells. Archives of Biochemistry and Biophysics. 2004; 431:71-78. [PubMed: 15464728]

Kinet JP. The high-affinity IgE receptor (FceRI): From physiology to pathology. Annual Review of Immunology. 1999; 17:931-972.

Kirshenbaum AS, Kessler SW, Goff JP, Metcalfe DD. Demonstration of the origin of human mast cells from CD34 ${ }^{+}$bone marrow progenitor cells. Journal of Immunology. 1991; 146:1410-1415.

Kirshenbaum AS, Kettelhut BV, Metcalfe DD, Garriga MM. Mastocytosis in infants and children: Recognition of patterns of skin disease. Allergy Proceedings. 1989; 10:17-21. [PubMed: 2925086]

Kischer CW, Bunce H III, Shetlah MR. Mast cell analyses in hypertrophic scars, hypertrophic scars treated with pressure and mature scars. The Journal of Investigative Dermatology. 1978; 70:355357. [PubMed: 649983]

Kitamura Y, Go S, Hatanaka K. Decrease of mast cells in $W / W^{v}$ mice and their increase by bone marrow transplantation. Blood. 1978; 52:447-452. [PubMed: 352443]

Kitamura Y, Shimada M, Go S. Presence of mast cell precursors in fetal liver of mice. Developmental Biology. 1979; 70:510-514. [PubMed: 478173]

Kitamura Y, Shimada M, Hatanaka K, Miyano Y. Development of mast cells from grafted bone marrow cells in irradiated mice. Nature. 1977; 268:442-443. [PubMed: 331117]

Knight PA, Wright SH, Lawrence CE, Paterson YY, Miller HR. Delayed expulsion of the nematode Trichinella spiralis in mice lacking the mucosal mast cell-specific granule chymase, mouse mast cell protease-1. The Journal of Experimental Medicine. 2000; 192:1849-1856. [PubMed: 11120781]

Kovanen PT. Mast cells and degradation of pericellular and extracellular matrices: Potential contributions to erosion, rupture and intraplaque haemorrhage of atherosclerotic plaques. Biochemical Society Transactions. 2007; 35:857-861. [PubMed: 17956232]

Kraft S, Kinet JP. New developments in FceRI regulation, function and inhibition. Nature Reviews Immunology. 2007; 7:365-378.

Kube P, Audige L, Kuther K, Welle M. Distribution, density and heterogeneity of canine mast cells and influence of fixation techniques. Histochemistry and Cell Biology. 1998; 110:129-135. [PubMed: 9720985]

Kunori Y, Koizumi M, Masegi T, Kasai H, Kawabata H, Yamazaki Y, et al. Rodent a-chymases are elastase-like proteases. European Journal of Biochemistry. 2002; 269:5921-5930. [PubMed: 12444981]

Kupietzky A, Levi-Schaffer F. The role of mast cell-derived histamine in the closure of an in vitro wound. Inflammation Research. 1996; 45:176-180. [PubMed: 8741007] 
Kurashima Y, Amiya T, Nochi T, Fujisawa K, Haraguchi T, Iba H, et al. Extracellular ATP mediates mast cell-dependent intestinal inflammation through $\mathrm{P} 2 \mathrm{X} 7$ purinoceptors. Nature Communications. 2012; 3:1034.

Lee DM, Friend DS, Gurish MF, Benoist C, Mathis D, Brenner MB. Mast cells: A cellular link between autoantibodies and inflammatory arthritis. Science. 2002; 297:1689-1692. [PubMed: 12215644]

Lees M, Taylor DJ, Woolley DE. Mast cell proteinases activate precursor forms of collagenase and stromelysin, but not of gelatinases A and B. European Journal of Biochemistry. 1994; 223:171177. [PubMed: 8033891]

Le Trong H, Parmelee DC, Walsh KA, Neurath H, Woodbury RG. Amino acid sequence of rat mast cell protease I (chymase). Biochemistry. 1987; 26:6988-6994. [PubMed: 3122823]

Levi-Schaffer F, Austen KF, Gravallese PM, Stevens RL. Coculture of interleukin-3-dependent mouse mast cells with fibroblasts results in a phenotypic change of the mast cells. Proceedings of the National Academy of Sciences of the United States of America. 1986; 83:6485-6488. [PubMed: 3462707]

Levi-Schaffer F, Dayton ET, Austen KF, Hein A, Caulfield JP, Gravallese PM, et al. Mouse bone marrow-derived mast cells cocultured with fibroblasts: Mor- phology and stimulation-induced release of histamine, leukotriene $\mathrm{B}_{4}$, leukotriene $\mathrm{C}_{4}$, and prostaglandin $\mathrm{D}_{2}$. Journal of Immunology. 1987; 139:3431-3441.

Levi-Schaffer F, Kupietzky A. Mast cells enhance migration and proliferation of fibroblasts into an in vitro wound. Experimental Cell Research. 1990; 188:42-49. [PubMed: 2328776]

Lewis RA, Soter NA, Diamond PT, Austen KF, Oates JA, Roberts LJ. Prostaglandin $\mathrm{D}_{2}$ generation after activation of rat and human mast cells with anti-IgE. Journal of Immunology. 1982; 129:1627-1631.

Li Y, Li L, Wadley R, Reddel SW, Qi JC, Archis C, et al. Mast cells/basophils in the peripheral blood of allergic individuals who are HIV-1 susceptible due to their surface expression of CD4 and the chemokine receptors CCR3, CCR5, and CXCR4. Blood. 2001; 97:3484-3490. [PubMed: 11369641]

Lin L, Bankaitis E, Heimbach L, Li N, Abrink M, Pejler G, et al. Dual targets for mouse mast cell protease-4 in mediating tissue damage in experimental bullous pemphigoid. The Journal of Biological Chemistry. 2011; 286:37358-37367. [PubMed: 21880713]

Longley BJ, Tyrrell L, Lu SZ, Ma YS, Langley K, Ding TG, et al. Somatic c-kit activating mutation in urticaria pigmentosa and aggressive mastocytosis: Establishment of clonality in a human mast cell neoplasm. Nature Genetics. 1996; 12:312-314. [PubMed: 8589724]

Lützelschwab C, Huang MR, Kullberg MC, Aveskogh M, Hellman L. Characterization of mouse mast cell protease-8, the first member of a novel subfamily of mouse mast cell serine proteases, distinct from both the classical chymases and tryptases. European Journal of Immunology. 1998; 28:1022-1033. [PubMed: 9541598]

Lützelschwab C, Pejler G, Aveskogh M, Hellman L. Secretory granule proteases in rat mast cells: Cloning of 10 different serine proteases and a carboxypeptidase A from various rat mast cell populations. The Journal of Experimental Medicine. 1997; 185:13-29. [PubMed: 8996238]

Maekawa A, Austen KF, Kanaoka Y. Targeted gene disruption reveals the role of cysteinyl leukotriene 1 receptor in the enhanced vascular permeability of mice undergoing acute inflammatory responses. The Journal of Biological Chemistry. 2002; 277:20820-20824. [PubMed: 11932261]

Magarinos NJ, Bryant KJ, Fosang AJ, Adachi R, Stevens RL, McNeil HP. Mast cell-restricted, tetramer-forming tryptases induce aggrecanolysis in articular cartilage by activating matrix metalloproteinase-3 and -13 zymogens. Journal of Immunology. 2013; 191:1404-1412.

Malbec O, Daeron M. The mast cell IgG receptors and their roles in tissue inflammation. Immunological Reviews. 2007; 217:206-221. [PubMed: 17498061]

Malbec O, Fridman WH, Daeron M. Negative regulation of c-kit-mediated cell proliferation by Fc $\gamma$ RIIB. Journal of Immunology. 1999; 162:4424-4429.

Martin FH, Suggs SV, Langley KE, Lu HS, Ting J, Okino KH, et al. Primary structure and functional expression of rat and human stem cell factor DNAs. Cell. 1990; 63:203-211. [PubMed: 2208279] 
Matsushima H, Yamada N, Matsue H, Shimada S. TLR3-, TLR7-, and TLR9-mediated production of proinflammatory cytokines and chemokines from murine connective tissue type skin-derived mast cells but not from bone marrow-derived mast cells. Journal of Immunology. 2004; 173:531541.

Maurer M, Fischer E, Handjiski B, von Stebut E, Algermissen B, Bavandi A, et al. Activated skin mast cells are involved in murine hair follicle regression (catagen). Laboratory Investigation. 1997; 77:319-332. [PubMed: 9354767]

McCurdy JD, Olynych TJ, Maher LH, Marshall JS. Cutting edge: Distinct Toll-like receptor 2 activators selectively induce different classes of mediator production from human mast cells. Journal of Immunology. 2003; 170:1625-1629.

McGivney A, Crews FT, Hirata F, Axelrod J, Siraganian RP. Rat basophilic leukemia cell lines defective in phospholipid methyltransferase enzymes, Ca2+ influx, and histamine release: Reconstitution by hybridization. Proceedings of the National Academy of Sciences of the United States of America. 1981; 78:6176-6180. [PubMed: 6171812]

McNeil HP, Austen KF, Somerville LL, Gurish MF, Stevens RL. Molecular cloning of the mouse mast cell protease 5 gene: A novel secretory granule protease expressed early in the differentiation of serosal mast cells. The Journal of Biological Chemistry. 1991; 266:20316-20322. [PubMed: 1939089]

McNeil HP, Reynolds DS, Schiller V, Ghildyal N, Gurley DS, Austen KF, et al. Isolation, characterization, and transcription of the gene encoding mouse mast cell protease 7. Proceedings of the National Academy of Sciences of the United States of America. 1992; 89:11174-11178. [PubMed: 1454796]

McNeil HP, Shin K, Campbell IK, Wicks IP, Adachi R, Lee DM, et al. The mouse mast cell-restricted tetramer-forming tryptases mouse mast cell protease 6 and mouse mast cell protease 7 are critical mediators in inflammatory arthritis. Arthritis and Rheumatism. 2008; 58:2338-2346. [PubMed: 18668540]

Mekori YA, Galli SJ. [ ${ }^{125}$ I]Fibrin deposition occurs at both early and late intervals of IgE-dependent or contact sensitivity reactions elicited in mouse skin: Mast cell-dependent augmentation of fibrin deposition at early intervals in combined IgE-dependent and contact sensitivity reactions. Journal of Immunology. 1990; 145:3719-3727.

Metcalfe DD, Baram D, Mekori YA. Mast cells. Physiological Reviews. 1997; 77:1033-1079. [PubMed: 9354811]

Metzger H, Goetze A, Kanellopoulos J, Holowka D, Fewtrell C. Structure of the high-affinity mast cell receptor for IgE. Federation Proceedings. 1982; 41:8-11. [PubMed: 6459957]

Miller JS, Moxley G, Schwartz LB. Cloning and characterization of a second complementary DNA for human tryptase. The Journal of Clinical Investigation. 1990; 86:864-870. [PubMed: 2203827]

Moon TC, St Laurent CD, Morris KE, Marcet C, Yoshimura T, Sekar Y, et al. Advances in mast cell biology: New understanding of heterogeneity and function. Mucosal Immunology. 2010; 3:111128. [PubMed: 20043008]

Moriguchi T, Fujimoto D. Crosslink of collagen in hypertrophic scar. The Journal of Investigative Dermatology. 1979; 72:143-145. [PubMed: 422877]

Morii E, Jippo T, Tsujimura T, Hashimoto K, Kim DK, Lee YM, et al. Abnormal expression of mouse mast cell protease 5 gene in cultured mast cells derived from mutant mi/mi mice. Blood. 1997; 90:3057-3066. [PubMed: 9376586]

Morii E, Tsujimura T, Jippo T, Hashimoto K, Takebayashi K, Tsujino K, et al. Regulation of mouse mast cell protease 6 gene expression by transcription factor encoded by the $m i$ locus. Blood. 1996; 88:2488-2494. [PubMed: 8839840]

Moulin V, Castilloux G, Auger FA, Garrel D, O’Connor-McCourt MD, Germain L. Modulated response to cytokines of human wound healing myofibroblasts compared to dermal fibroblasts. Experimental Cell Research. 1998; 238:283-293. [PubMed: 9457082]

Moyer KE, Saggers GC, Ehrlich HP. Mast cells promote fibroblast populated collagen lattice contraction through gap junction intercellular communication. Wound Repair and Regeneration. 2004; 12:269-275. [PubMed: 15225205] 
Murakami M, Ikeda T, Ogawa K, Funaba M. Transcriptional activation of mouse mast cell protease-9 by microphthalmia-associated transcription factor. Biochemical and Biophysical Research Communications. 2003; 311:4-10. [PubMed: 14575687]

Muramatsu M, Katada J, Hattori M, Hayashi I, Majima M. Chymase mediates mast cell-induced angiogenesis in hamster sponge granulomas. European Journal of Pharmacology. 2000; 402:181191. [PubMed: 10940372]

Nagata H, Okada T, Worobec AS, Semere T, Metcalfe DD. c-kit mutation in a population of patients with mastocytosis. International Archives of Allergy and Immunology. 1997; 113:184-186. [PubMed: 9130517]

Nakamura Y, Kambe N, Saito M, Nishikomori R, Kim YG, Murakami M, et al. Mast cells mediate neutrophil recruitment and vascular leakage through the NLRP3 inflammasome in histamineindependent urticaria. The Journal of Experimental Medicine. 2009; 206:1037-1046. [PubMed: 19364881]

Nakano T, Kanakura Y, Asai H, Kitamura Y. Changing processes from bone marrow-derived cultured mast cells to connective tissue-type mast cells in the peritoneal cavity of mast cell-deficient $W / W^{v}$ mice: Association of proliferation arrest and differentiation. Journal of Immunology. 1987; 138:544-549.

Nakano T, Sonoda T, Hayashi C, Yamatodani A, Kanayama Y, Yamamura T, et al. Fate of bone marrow-derived cultured mast cells after intracutaneous, intraperitoneal, and intravenous transfer into genetically mast cell-deficient $W / W^{v}$ mice: Evidence that cultured mast cells can give rise to both connective tissue and muosal mast cells. The Journal of Experimental Medicine. 1985; 162:1025-1043. [PubMed: 3897446]

$\mathrm{Ng}$ MF. The role of mast cells in wound healing. International Wound Journal. 2010; 7:55-61. [PubMed: 20409251]

Nigrovic PA, Gray DH, Jones T, Hallgren J, Kuo FC, Chaletzky B, et al. Genetic inversion in mast cell-deficient $W^{\text {sh }}$ mice interrupts corin and manifests as hematopoietic and cardiac aberrancy. The American Journal of Pathology. 2008; 173:1693-1701. [PubMed: 18988802]

Nishikori Y, Kakizoe E, Kobayashi Y, Shimoura K, Okunishi H, Dekio S. Skin mast cell promotion of matrix remodeling in burn wound healing in mice: Relevance of chymase. Archives of Dermatological Research. 1998; 290:553-560. [PubMed: 9836506]

Noli C, Miolo A. The mast cell in wound healing. Veterinary Dermatology. 2001; 12:303-313. [PubMed: 11844219]

Noli C, Miolo A. The role of mast cells in the early stages of wound healing. International Wound Journal. 2010; 7:540. [PubMed: 21073684]

Norrby K, Jakobsson A, Sorbo J. Mast-cell-mediated angiogenesis: A novel experimental model using the rat mesentery. Virchows Archiv B, Cell Pathology Including Molecular Pathology. 1986; 52:195-206.

Norrby K, Sorbo J. Heparin enhances angiogenesis by a systemic mode of action. International Journal of Experimental Pathology. 1992; 73:147-155. [PubMed: 1373951]

Oh SW, Pae CI, Lee DK, Jones F, Chiang GK, Kim HO, et al. Tryptase inhibition blocks airway inflammation in a mouse asthma model. Journal of Immunology. 2002; 168:1992-2000.

Otsu K, Nakano T, Kanakura Y, Asai H, Katz HR, Austen KF, et al. Phenotypic changes of bone marrow-derived mast cells after intraperitoneal transfer into $W / W^{v}$ mice that are genetically deficent in mast cells. The Journal of Experimental Medicine. 1987; 165:615-627. [PubMed: 3102674]

Padawer J. Mast cells: Extended lifespan and lack of granule turnover under normal in vivo conditions. Experimental and Molecular Pathology. 1974; 20:269-280. [PubMed: 4363128]

Pallaoro M, Fejzo MS, Shayesteh L, Blount JL, Caughey GH. Characterization of genes encoding known and novel human mast cell tryptases on chromosome 16p13.3. The Journal of Biological Chemistry. 1999; 274:3355-3362. [PubMed: 9920877]

Pemberton AD, Huntley JF, Miller HR. Differential inhibition of mast cell chymases by secretory leukocyte protease inhibitor. Biochimica et Biophysica Acta. 1998; 1379:29-34. [PubMed: 9468329] 
Pemberton AD, Wright SH, Knight PA, Miller HR. Anaphylactic release of mucosal mast cell granule proteases: Role of serpins in the differential clearance of mouse mast cell proteases- 1 and -2 . Journal of Immunology. 2006; 176:899-904.

Pennock JL, Grencis RK. The mast cell and gut nematodes: Damage and defence. Chemical Immunology and Allergy. 2006; 90:128-140. [PubMed: 16210907]

Pimentel TA, Sampaio AL, D’Acquisto F, Perretti M, Oliani SM. An essential role for mast cells as modulators of neutrophils influx in collagen-induced arthritis in the mouse. Laboratory Investigation. 2011; 91:33-42. [PubMed: 20714326]

Placik OJ, Lewis VL Jr. Immunologic associations of keloids. Surgery, Gynecology \& Obstetrics. 1992; 175:185-193.

Prieto-Garcia A, Zheng D, Adachi R, Xing W, Lane WS, Chung K, et al. Mast cell restricted mouse and human tryptase-heparin complexes hinder thrombin-induced coagulation of plasma and the generation of fibrin by proteolytically destroying fibrinogen. The Journal of Biological Chemistry. 2012; 287:7834-7844. [PubMed: 22235124]

Qu Z, Kayton RJ, Ahmadi P, Liebler JM, Powers MR, Planck SR, et al. Ultrastructural immunolocalization of basic fibroblast growth factor in mast cell secretory granules: Morphological evidence for bFGF release through degranulation. The Journal of Histochemistry and Cytochemistry. 1998; 46:1119-1128. [PubMed: 9742068]

Razin E, Cordon-Cardo C, Good RA. Growth of a pure population of mouse mast cells in vitro with conditioned medium derived from concanavalin A-stimulated splenocytes. Proceedings of the National Academy of Sciences of the United States of America. 1981; 78:2559-2561. [PubMed: 6166010]

Razin E, Ihle JN, Seldin D, Mencia-Huerta JM, Katz HR, LeBlanc PA, et al. Interleukin-3: A differentiation and growth factor for the mouse mast cell that contains chondroitin sulfate $\mathrm{E}$ proteoglycan. Journal of Immunology. 1984; 132:1479-1486.

Razin E, Marx G. Thrombin-induced degranulation of cultured bone marrow-derived mast cells. Journal of Immunology. 1984; 133:3282-3285.

Razin E, Stevens RL, Akiyama F, Schmid K, Austen KF. Culture from mouse bone marrow of a subclass of mast cells possessing a distinct chondroitin sulfate proteoglycan with glycosaminoglycans rich in $\mathrm{N}$-acetylgalactosamine-4,6-disulfate. The Journal of Biological Chemistry. 1982; 257:7229-7236. [PubMed: 6806269]

Razin E, Stevens RL, Austen KF, Caulfield JP, Hein A, Liu FT, et al. Cloned mouse mast cells derived from immunized lymph node cells and from fetal liver cells exhibit characteristics of bone marrow-derived mast cells containing chondroitin sulphate E proteoglycan. Immunology. 1984; 52:563-575. [PubMed: 6745997]

Reynolds DS, Gurley DS, Austen KF, Serafin WE. Cloning of the cDNA and gene of mouse mast cell protease 6: Transcription by progenitor mast cells and mast cells of the connective tissue subclass. The Journal of Biological Chemistry. 1991; 266:3847-3853. [PubMed: 1995638]

Reynolds DS, Gurley DS, Stevens RL, Sugarbaker DJ, Austen KF, Serafin WE. Cloning of cDNAs that encode human mast cell carboxypeptidase A, and comparison of the protein with mouse mast cell carboxypeptidase A and rat pancreatic carboxypeptidases. Proceedings of the National Academy of Sciences of the United States of America. 1989; 86:9480-9484. [PubMed: 2594780]

Reynolds DS, Stevens RL, Gurley DS, Lane WS, Austen KF, Serafin WE. Isolation and molecular cloning of mast cell carboxypeptidase A: A novel member of the carboxypeptidase gene family. The Journal of Biological Chemistry. 1989; 264:20094-20099. [PubMed: 2584208]

Rivera J, Gilfillan AM. Molecular regulation of mast cell activation. The Journal of Allergy and Clinical Immunology. 2006; 117:1214-1225. [PubMed: 16750977]

Rodgers K, Xiong S. Contributions of inflammatory mast cell mediators to alterations in macrophage function after malathion administration. International Journal of Immunopharmacology. 1997; 19:149-156. [PubMed: 9306154]

Ronnstrand L. Signal transduction via the stem cell factor receptor/c-Kit. Cellular and Molecular Life Sciences. 2004; 61:2535-2548. [PubMed: 15526160]

Rosenberg RD. Heparin, antithrombin, and abnormal clotting. Annual Review of Medicine. 1978; 29:367-378. 
Russel JD, Russell SB, Trupin KM. The effect of histamine on the growth of cultured fibroblasts isolated from normal and keloid tissue. Journal of Cellular Physiology. 1977; 93:389-393. [PubMed: 591568]

Saarinen J, Kalkkinen N, Welgus HG, Kovanen PT. Activation of human interstitial procollagenase through direct cleavage of the Leu ${ }^{83}-\mathrm{Thr}^{84}$ bond by mast cell chymase. The Journal of Biological Chemistry. 1994; 269:18134-18140. [PubMed: 8027075]

Schechter NM, Irani AM, Sprows JL, Abernethy J, Wintroub B, Schwartz LB. Identification of a cathepsin G-like proteinase in the $\mathrm{MC}_{\mathrm{TC}}$ type of human mast cell. Journal of Immunology. 1990; 145:2652-2661.

Schechter NM, Wang ZM, Blacher RW, Lessin SR, Lazarus GS, Rubin H. Determination of the primary structures of human skin chymase and cathepsin $\mathrm{G}$ from cutaneous mast cells of urticaria pigmentosa lesions. Journal of Immunology. 1994; 152:4062-4069.

Schilling JA. Wound healing. Surgical Clinics of North America. 1976; 56:859-874. [PubMed: 959948]

Schrader JW, Lewis SJ, Clark-Lewis I, Culvenor JG. The persisting (P) cell: Histamine content, regulation by a $\mathrm{T}$ cell-derived factor, origin from a bone marrow precursor, and relationship to mast cells. Proceedings of the National Academy of Sciences of the United States of America. 1981; 78:323-327. [PubMed: 6972532]

Schwartz LB, Lewis RA, Austen KF. Tryptase from human pulmonary mast cells: Purification and characterization. The Journal of Biological Chemistry. 1981; 256:11939-11943. [PubMed: 7028744]

Scudamore CL, Jepson MA, Hirst BH, Miller HR. The rat mucosal mast cell chymase, rMCP-II, alters epithelial cell monolayer permeability in association with altered distribution of the tight junction proteins ZO-1 and occludin. European Journal of Cell Biology. 1998; 75:321-330. [PubMed: 9628318]

Serafin WE, Reynolds DS, Rogelj S, Lane WS, Conder GA, Johnson SS, et al. Identification and molecular cloning of a novel mouse mucosal mast cell serine protease. The Journal of Biological Chemistry. 1990; 265:423-429. [PubMed: 1688433]

Serafin WE, Sullivan TP, Conder GA, Ebrahimi A, Marcham P, Johnson SS, et al. Cloning of the cDNA and gene for mouse mast cell protease 4: Demonstration of its late transcription in mast cell subclasses and analysis of its homology to subclass-specific neutral proteases of the mouse and rat. The Journal of Biological Chemistry. 1991; 266:1934-1941. [PubMed: 1988455]

Shaker SA, Ayuob NN, Hajrah NH. Cell talk: A phenomenon observed in the keloid scar by immunohistochemical study. Applied Immunohistochemistry \& Molecular Morphology. 2011; 19:153-159. [PubMed: 20881838]

Shin K, Nigrovic PA, Crish J, Boilard E, McNeil HP, Larabee KS, et al. Mast cells contribute to autoimmune inflammatory arthritis via their tryptase/heparin complexes. Journal of Immunology. 2009; 182:647-656.

Shin K, Watts GF, Oettgen HC, Friend DS, Pemberton AD, Gurish MF, et al. Mouse mast cell tryptase mMCP-6 is a critical link between adaptive and innate immunity in the chronic phase of Trichinella spiralis infection. Journal of Immunology. 2008; 180:4885-4891.

Sinnamon MJ, Carter KJ, Sims LP, Lafleur B, Fingleton B, Matrisian LM. A protective role of mast cells in intestinal tumorigenesis. Carcinogenesis. 2008; 29:880-886. [PubMed: 18258601]

Sonoda S, Sonoda T, Nakano T, Kanayama Y, Kanakura Y, Asai H, et al. Development of mucosal mast cells after injection of a single connective tissue-type mast cell in the stomach mucosa of genetically mast cell-deficient $W / W^{\nu}$ mice. Journal of Immunology. 1986; 137:1319-1322.

Stevens RL, Austen KF. Effect of p-nitrophenyl- $\beta$-D-xyloside on proteoglycan and glycosaminoglycan biosynthesis in rat serosal mast cell cultures. The Journal of Biological Chemistry. 1982; 257:253-259. [PubMed: 7053369]

Stevens RL, Lee TD, Seldin DC, Austen KF, Befus AD, Bienenstock J. Intestinal mucosal mast cells from rats infected with Nippostrongylus brasiliensis contain protease-resistant chondroitin sulfate diB proteoglycans. Journal of Immunology. 1986; 137:291-295. 
Stevens RL, Nicodemus CF, Avraham S. The gene that encodes the peptide core of secretory granule proteoglycans of haematopoietic cells. Biochemical Society Transactions. 1990; 18:810-812. [PubMed: 2083683]

Strik MC, de Koning PJ, Kleijmeer MJ, Bladergroen BA, Wolbink AM, Griffith JM, et al. Human mast cells produce and release the cytotoxic lymphocyte associated protease granzyme B upon activation. Molecular Immunology. 2007; 44:3462-3472. [PubMed: 17485116]

Suber F, Carroll MC, Moore FD Jr. Innate response to self-antigen significantly exacerbates burn wound depth. Proceedings of the National Academy of Sciences of the United States of America. 2007; 104:3973-3977. [PubMed: 17360462]

Sudo N, Tanaka K, Koga Y, Okumura Y, Kubo C, Nomoto K. Extracellular ATP activates mast cells via a mechanism that is different from the activation induced by the cross-linking of Fc receptors. Journal of Immunology. 1996; 156:3970-3979.

Sun J, Sukhova GK, Yang M, Wolters PJ, MacFarlane LA, Libby P, et al. Mast cells modulate the pathogenesis of elastase-induced abdominal aortic aneurysms in mice. The Journal of Clinical Investigation. 2007; 117:3359-3368. [PubMed: 17932568]

Sun J, Zhang J, Lindholt JS, Sukhova GK, Liu J, He A, et al. Critical role of mast cell chymase in mouse abdominal aortic aneurysm formation. Circulation. 2009; 120:973-982. [PubMed: 19720934]

Taipale J, Lohi J, Saarinen J, Kovanen PT, Keski-Oja J. Human mast cell chymase and leukocyte elastase release latent transforming growth factor- $\beta 1$ from the extracellular matrix of cultured human epithelial and endothelial cells. The Journal of Biological Chemistry. 1995; 270:46894696. [PubMed: 7876240]

Taub DD, Mikovits JA, Nilsson G, Schaffer EM, Key ML, Petrow-Sadowski C, et al. Alterations in mast cell function and survival following in vitro infection with human immunodeficiency viruses-1 through CXCR4. Cellular Immunology. 2004; 230:65-80. [PubMed: 15598422]

Tchougounova E, Lundequist A, Fajardo I, Winberg JO, Abrink M, Pejler G. A key role for mast cell chymase in the activation of promatrix metalloprotease- 9 and promatrix metalloprotease- 2 . The Journal of Biological Chemistry. 2005; 280:9291-9296. [PubMed: 15615702]

Tchougounova E, Pejler G, Abrink M. The chymase, mouse mast cell protease 4, constitutes the major chymotrypsin-like activity in peritoneum and ear tissue; a role for mouse mast cell protease 4 in thrombin regulation and fibronectin turnover. The Journal of Experimental Medicine. 2003; 198:423-431. [PubMed: 12900518]

Thakurdas SM, Melicoff E, Sansores-Garcia L, Moreira DC, Petrova Y, Stevens RL, et al. The mast cell-restricted tryptase mMCP-6 has a critical immunoprotective role in bacterial infections. The Journal of Biological Chemistry. 2007; 282:20809-20815. [PubMed: 17456473]

Thomas VA, Wheeless CJ, Stack MS, Johnson DA. Human mast cell tryptase fibrinogenolysis: Kinetics, anticoagulation mechanism, and cell adhesion disruption. Biochemistry. 1998; 37:2291-2298. [PubMed: 9485375]

Trautmann A, Toksoy A, Engelhardt E, Brocker EB, Gillitzer R. Mast cell involvement in normal human skin wound healing: Expression of monocyte chemoattractant protein-1 is correlated with recruitment of mast cells which synthesize interleukin-4 in vivo. The Journal of Pathology. 2000; 190:100-106. [PubMed: 10640999]

Trong HL, Newlands GF, Miller HR, Charbonneau H, Neurath H, Woodbury RG. Amino acid sequence of a mouse mucosal mast cell protease. Biochemistry. 1989; 28:391-395. [PubMed: 2706264]

Tsai M, Grimbaldeston M, Galli SJ. Mast cells and immunoregulation/immunomodulation. Advances in Experimental Medicine and Biology. 2011; 716:186-211. [PubMed: 21713658]

Tsai M, Shih LS, Newlands GF, Takeishi T, Langley KE, Zsebo KM, et al. The rat c-kit ligand, stem cell factor, induces the development of connective tissue-type and mucosal mast cells in vivo: Analysis by anatomical distribution, histochemistry, and protease phenotype. The Journal of Experimental Medicine. 1991; 174:125-131. [PubMed: 1711559]

Tsai M, Tam SY, Wedemeyer J, Galli SJ. Mast cells derived from embryonic stem cells: A model system for studying the effects of genetic manipulations on mast cell development, phenotype, 
and function in vitro and in vivo. International Journal of Hematology. 2002; 75:345-349.

[PubMed: 12041662]

Tsujimura T, Furitsu T, Morimoto M, Kanayama Y, Nomura S, Matsuzawa Y, et al. Substitution of an aspartic acid results in constitutive activation of c-kit receptor tyrosine kinase in a rat tumor mast cell line RBL-2H3. International Archives of Allergy and Immunology. 1995; 106:377-385. [PubMed: 7536501]

Urata H, Kinoshita A, Perez DM, Misono KS, Bumpus FM, Graham RM, et al. Cloning of the gene and cDNA for human heart chymase. The Journal of Biological Chemistry. 1991; 266:1717317179. [PubMed: 1894611]

Vanderslice P, Ballinger SM, Tam EK, Goldstein SM, Craik CS, Caughey GH. Human mast cell tryptase: Multiple cDNAs and genes reveal a multigene serine protease family. Proceedings of the National Academy of Sciences of the United States of America. 1990; 87:3811-3815. [PubMed: 2187193]

Vliagoftis H. Thrombin induces mast cell adhesion to fibronectin: Evidence for involvement of protease-activated receptor-1. Journal of Immunology. 2002; 169:4551-4558.

Walsh JC, DeKoter RP, Lee HJ, Smith ED, Lancki DW, Gurish MF, et al. Cooperative and antagonistic interplay between PU.1 and GATA-2 in the specification of myeloid cell fates. Immunity. 2002; 17:665-676. [PubMed: 12433372]

Wastling JM, Scudamore CL, Thornton EM, Newlands GF, Miller HR. Constitutive expression of mouse mast cell protease-1 in normal BALB/c mice and its upregulation during intestinal nematode infection. Immunology. 1997; 90:308-313. [PubMed: 9135562]

Weber A, Knop J, Maurer M. Pattern analysis of human cutaneous mast cell populations by total body surface mapping. The British Journal of Dermatology. 2003; 148:224-228. [PubMed: 12588371]

Welham MJ, Schrader JW. Steel factor-induced tyrosine phosphorylation in murine mast cells: Common elements with IL-3-induced signal transduction pathways. Journal of Immunology. 1992; 149:2772-2783.

Weller K, Foitzik K, Paus R, Syska W, Maurer M. Mast cells are required for normal healing of skin wounds in mice. The FASEB Journal. 2006; 20:2366-2368.

Wolters PJ, Mallen-St CJ, Lewis CC, Villalta SA, Baluk P, Erle DJ, et al. Tissue-selective mast cell reconstitution and differential lung gene expression in mast cell-deficient $\mathrm{Kit}(\mathrm{W}$-sh)/Kit(W-sh) sash mice. Clinical and Experimental Allergy. 2005; 35:82-88. [PubMed: 15649271]

Wong GW, Foster PS, Yasuda S, Qi JC, Mahalingam S, Mellor EA, et al. Biochemical and functional characterization of human transmembrane tryptase (TMT)/ tryptase $\gamma$ : TMT is an exocytosed mast cell protease that induces airway hyper-responsiveness in vivo via an IL-13/IL-4Ra/ STAT6-dependent pathway. The Journal of Biological Chemistry. 2002; 277:41906-41915. [PubMed: 12194977]

Wong GW, Tang Y, Feyfant E, Šali A, Li L, Li Y, et al. Identification of a new member of the tryptase family of mouse and human mast cell proteases that possesses a novel C-terminal hydrophobic extension. The Journal of Biological Chemistry. 1999; 274:30784-30793. [PubMed: 10521469]

Wong GW, Yang Y, Yasuda S, Li L, Stevens RL. Mouse mast cells express the tryptic protease neuropsin/mPrss19. Biochemical and Biophysical Research Communications. 2003; 303:320325. [PubMed: 12646205]

Wong GW, Yasuda S, Madhusudhan MS, Li L, Yang Y, Krilis SA, et al. Human tryptase $\varepsilon$ (PRSS22), a new member of the chromosome 16p13.3 family of human serine proteases expressed in airway epithelial cells. The Journal of Biological Chemistry. 2001; 276:49169-49182. [PubMed: 11602603]

Wong GW, Yasuda S, Morokawa N, Li L, Stevens RL. Mouse chromosome 17A3.3 contains thirteen genes that encode functional tryptic-like serine proteases with distinct tissue and cell expression patterns. The Journal of Biological Chemistry. 2004; 279:2438-2452. [PubMed: 14583634]

Woodbury RG, Everitt M, Sanada Y, Katunuma N, Lagunoff D, Neurath H. A major serine protease in rat skeletal muscle: Evidence for its mast cell origin. Proceedings of the National Academy of Sciences of the United States of America. 1978; 75:5311-5313. [PubMed: 103093] 
Wulff BC, Parent AE, Meleski MA, Dipietro LA, Schrementi ME, Wilgus TA. Mast cells contribute to scar formation during fetal wound healing. The Journal of Investigative Dermatology. 2012; 132:458-465. [PubMed: 21993557]

Xia Z, Ghildyal N, Austen KF, Stevens RL. Post-transcriptional regulation of chymase expression in mast cells: A cytokine-dependent mechanism for controlling the expression of granule neutral proteases of hematopoietic cells. The Journal of Biological Chemistry. 1996; 271:8747-8753. [PubMed: 8621509]

Xing W, Austen KF, Gurish MF, Jones TG. Protease phenotype of constitutive connective tissue and of induced mucosal mast cells in mice is regulated by the tissue. Proceedings of the National Academy of Sciences of the United States of America. 2011; 108:14210-14215. [PubMed: 21825171]

Yamamoto T, Hartmann K, Eckes B, Krieg T. Mast cells enhance contraction of three-dimensional collagen lattices by fibroblasts by cell-cell interaction: Role of stem cell factor/c-kit. Immunology. 2000; 99:435-439. [PubMed: 10712674]

Yang Y, Li L, Wong GW, Krilis SA, Madhusudhan MS, SŠali A, et al. RasGRP4, a new mast cellrestricted Ras guanine nucleotide releasing protein with calcium- and diacylglycerol-binding motifs: Identification of defective variants of this signaling protein in asthma, mastocytosis, and mast cell leukemia patients and demonstration of the importance of RasGRP4 in mast cell development and function. The Journal of Biological Chemistry. 2002; 277:25756-25774. [PubMed: 11956218]

Younan GJ, Heit YI, Dastouri P, Kekhia H, Xing W, Gurish MF, et al. Mast cells are required in the proliferation and remodeling phases of microdeformational wound therapy. Plastic and Reconstructive Surgery. 2011; 128:649e-658e.

Younan G, Suber F, Xing W, Shi T, Kunori Y, Abrink M, et al. The inflammatory response after an epidermal burn depends on the activities of mouse mast cell proteases 4 and 5. Journal of Immunology. 2010; 185:7681-7690.

Yurt RW, Leid RW Jr, Austen KF. Native heparin from rat peritoneal mast cells. The Journal of Biological Chemistry. 1977; 252:518-521. [PubMed: 833141]

Zhang S, Cherwinski H, Sedgwick JD, Phillips JH. Molecular mechanisms of CD200 inhibition of mast cell activation. Journal of Immunology. 2004; 173:6786-6793.

Zhang S, Phillips JH. Identification of tyrosine residues crucial for CD200R-mediated inhibition of mast cell activation. Journal of Leukocyte Biology. 2006; 79:363-368. [PubMed: 16330532]

Zhang J, Sun J, Lindholt JS, Sukhova GK, Sinnamon M, Stevens RL, et al. Mast cell tryptase deficiency attenuates mouse abdominal aortic aneurysm formation. Circulation Research. 2011; 108:1316-1327. [PubMed: 21493897]

Zhao XY, Zhao LY, Zheng QS, Su JL, Guan H, Shang FJ, et al. Chymase induces profibrotic response via transforming growth factor- $\beta 1 /$ Smad activation in rat cardiac fibroblasts. Molecular and Cellular Biochemistry. 2008; 310:159-166. [PubMed: 18057996]

Zhou JS, Xing W, Friend DS, Austen KF, Katz HR. Mast cell deficiency in $\mathrm{Kit}^{W-s h}$ mice does not impair antibody-mediated arthritis. The Journal of Experimental Medicine. 2007; 204:27972802. [PubMed: 17998392]

Zon LI, Gurish MF, Stevens RL, Mather C, Reynolds DS, Austen KF, et al. GATA-binding transcription factors in mast cells regulate the promoter of the mast cell carboxypeptidase A gene. The Journal of Biological Chemistry. 1991; 266:22948-22953. [PubMed: 1744088] 
A

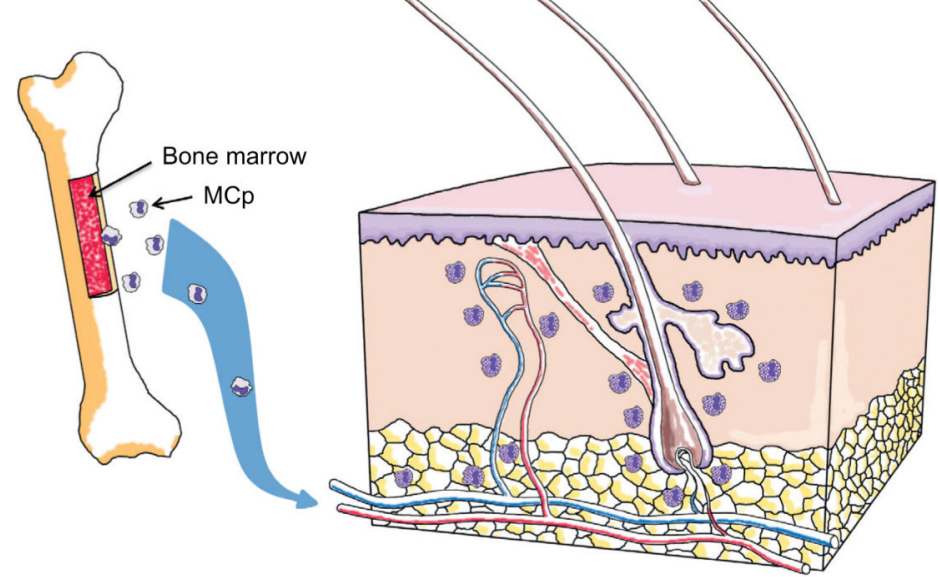

B

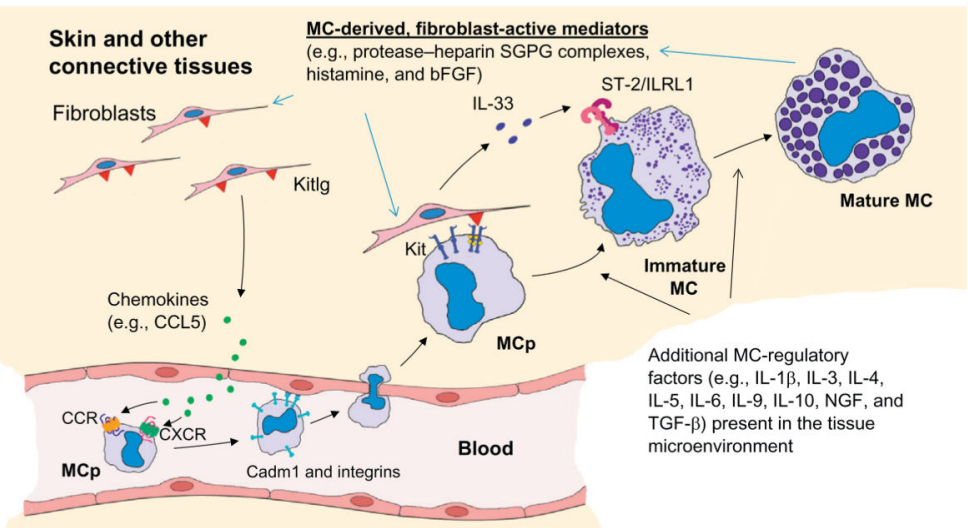

Figure 6.1.

Development of cutaneous MCs from their hematopoietic progenitors. The bone marrow (A) constitutively releases MC-committed progenitors (MCp) into the blood. These circulating, nongranulated $\mathrm{CD} 34^{+}$progenitors enter the skin and other organs when they encounter the appropriate combination of chemokines (e.g., Ccl5) and other recruitment factors (B). The retention of these progenitors in tissues also is highly dependent on Kitlg ( $\mathbf{\nabla})$, Kit, Cadm1, and varied integrins (I). Once in the skin, the progenitors undergo their final stages of differentiation and maturation. This includes their expression and granule accumulation of different combinations of protease-SGPG complexes. The phenotype of an MC at any stage of its life span is highly dependent on the factors the mature cell and its progenitor encounter in the tissue microenvironments. A mature MC can even reversibility alter what genes and proteins it expresses. Although fibroblast-derived Kitlg and IL-33 are essential in the development of cutaneous MCs, other cytokines (e.g., TGF- $\beta$ and IL-9) play important roles in determining what families of mediators are expressed. 


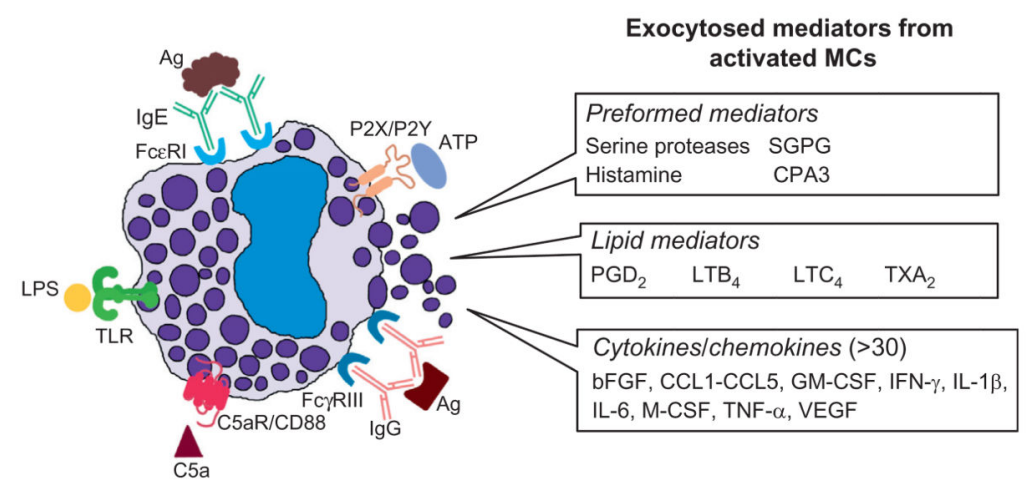

Figure 6.2.

Exocytosed mediators from activated MCs. The MCs that reside in the skin and other connective tissues contain numerous receptors on their plasma membranes that they use in innate (e.g., complement and TLRs) and acquired (e.g., FceRI and Fc $\gamma$ RIII) immunity. MCs also can recognize and respond to numerous endogenous factors like ATP that are often increased in wounded skin, as well as epitopes recognized by naturally occurring IgM autoantibodies. In the early phase, activated MCs rapidly exocytose the contents of their secretory granules and increase their expression of varied lipid mediators. In the late phase, the activated cell markedly increases the expression of numerous cytokines and chemokines. MCs also have inhibitory receptors that dampen cellular activation. 

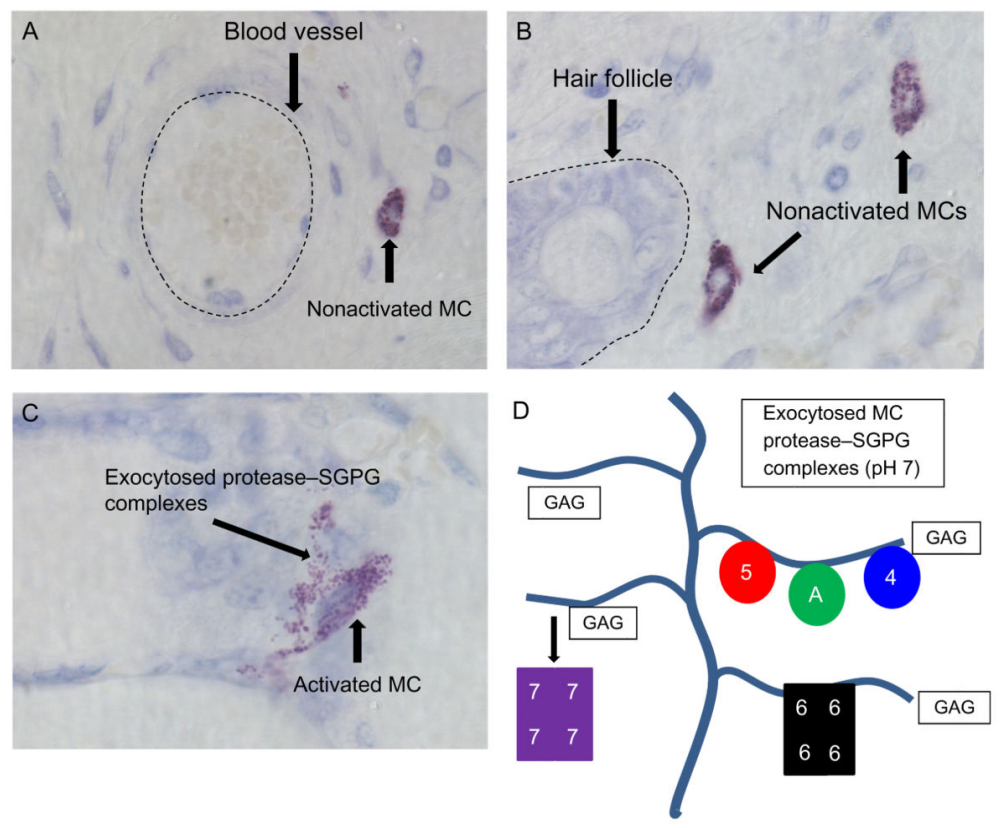

Figure 6.3.

Histochemistry of nonactivated and activated cutaneous MCs. Mature MCs are recognized in the skin and other tissues histochemically by the ability of their SGPGs to bind to toluidine blue and other cationic dyes. Cutaneous MCs tend to reside near blood vessels (A), hair follicles (B), and nerves (data not shown). When activated (C), cutaneous MCs quickly exocytose the content of their secretory granules which consist primarily of histamine and varied protease-SGPG complexes. Most of the cell's positively charged granule proteases (D) (e.g., mMCP-5 (5), Cpa3 (A), mMCP-4 (4), and mMCP-6 (6)) are ionically bound so tightly to the negatively charged glycosaminoglycans (GAGs) of SGPGs that the exocytosed macromolecular complexes remain intact for hours in the ECM. An exception is mMCP-7 (7), due to its less positively charged SGPG-binding domain. The large size of these protease-SGPG complexes minimize their diffusion and ability to enter the circulation. Instead, most of them are eventually endocytosed by other cell types in the inflammatory site where they are destroyed in primary lysosomes. The depicted images in panels (A)-(C) were from surgically wounded mouse skin. 


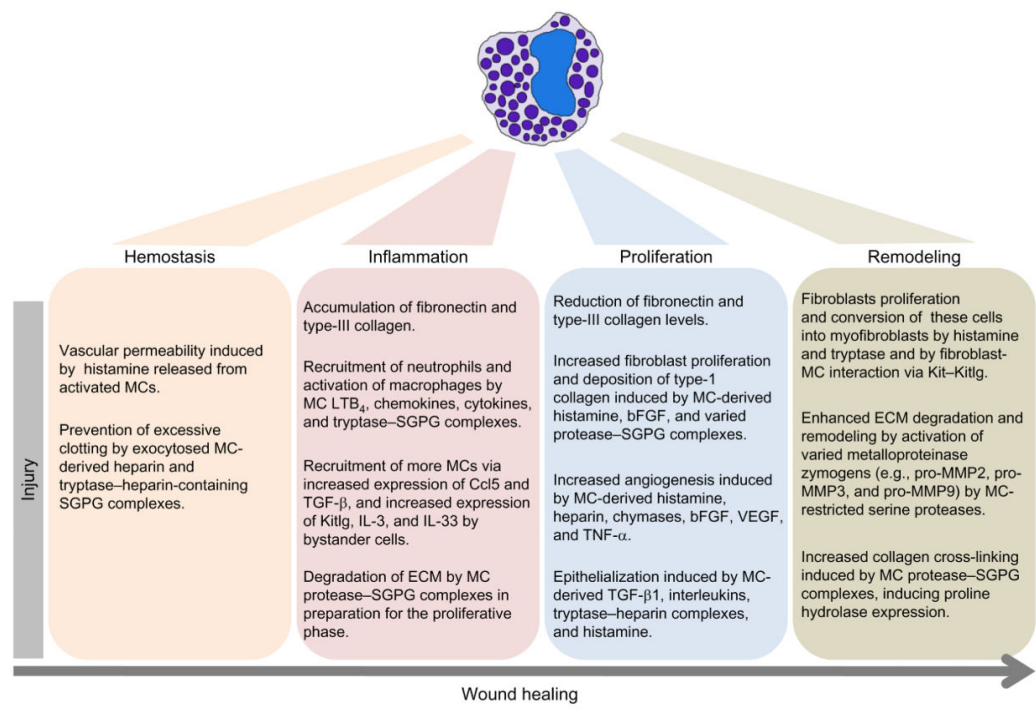

Figure 6.4.

Roles of MCs in different stages of wound repair. MCs and their mediators play important roles in hemostasis and in the inflammation, proliferation, and remodeling phases of wound healing. 


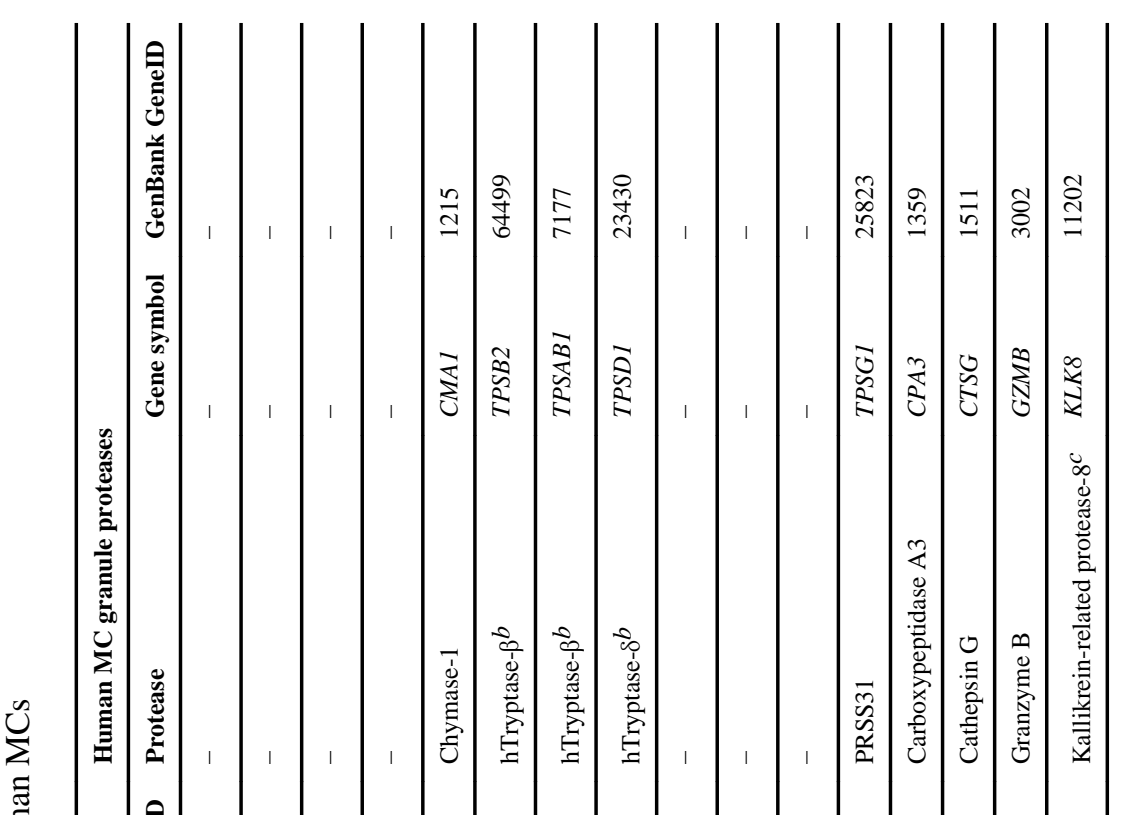

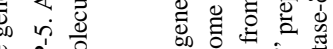

Ð 仓ิ

질 हु

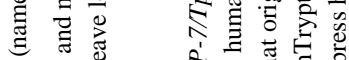

की

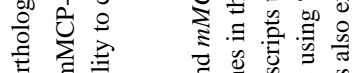

ह

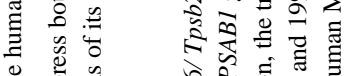

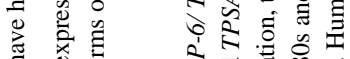

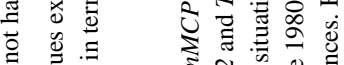

है

导离

उ ए

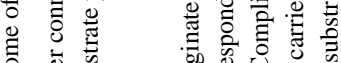

क्षे

बै

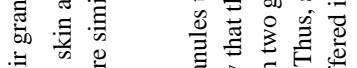

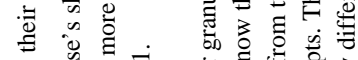

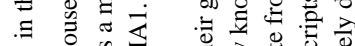

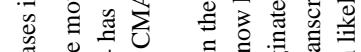

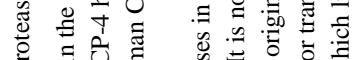

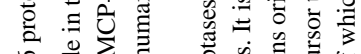

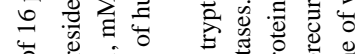

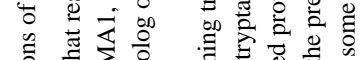

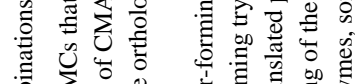

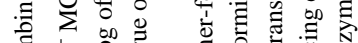

है + 응 छ

ठ

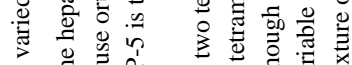

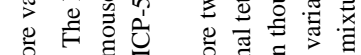

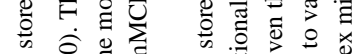

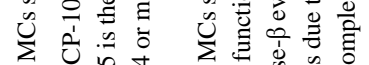

$\sum_{0}$ i $\sum_{0} \sum^{2}$

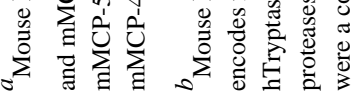




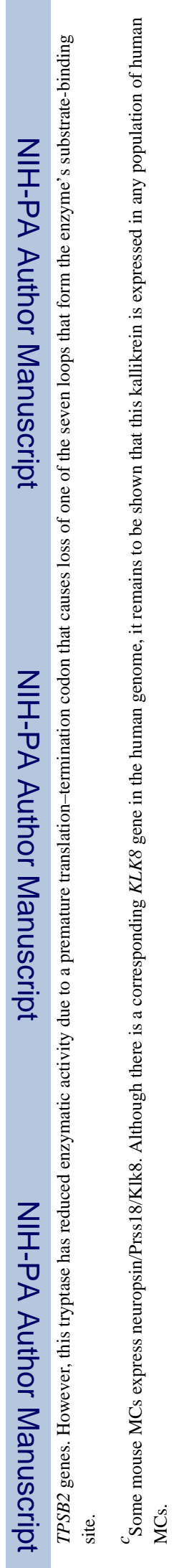

Adv Immunol. Author manuscript; available in PMC 2014 July 29. 